San Jose State University

SJSU ScholarWorks

Master's Theses

Master's Theses and Graduate Research

Summer 2010

\title{
Queering Hegemonies of Gender and Cultural Identity Through a Critical Adaptation of Maxine Hong Kingston's Novel The Woman Warrior
}

Julia Valentina Salvador

San Jose State University

Follow this and additional works at: https://scholarworks.sjsu.edu/etd_theses

\section{Recommended Citation}

Salvador, Julia Valentina, "Queering Hegemonies of Gender and Cultural Identity Through a Critical Adaptation of Maxine Hong Kingston's Novel The Woman Warrior" (2010). Master's Theses. 3827. DOI: https://doi.org/10.31979/etd.3q8q-4kjs https://scholarworks.sjsu.edu/etd_theses/3827

This Thesis is brought to you for free and open access by the Master's Theses and Graduate Research at SJSU ScholarWorks. It has been accepted for inclusion in Master's Theses by an authorized administrator of SJSU ScholarWorks. For more information, please contact scholarworks@sjsu.edu. 


\title{
QUEERING HEGEMONIES OF GENDER AND CULTURAL IDENTITY THROUGH A CRITICAL ADAPTATION OF MAXINE HONG KINGSTON'S NOVEL THE WOMAN WARRIOR
}

\author{
A Thesis \\ Presented to \\ The Faculty of the Department of Communication Studies \\ San José State University \\ In Partial Fulfillment \\ of the Requirements of the Degree \\ Master of Arts
}

by

Julia Valentina Salvador

August 2010 
(C) 2010

Julia Valentina Salvador

ALL RIGHTS RESERVED 
The Designated Thesis Committee Approves the Thesis Titled

QUEERING HEGEMONIES OF GENDER AND CULTURAL IDENTITY THROUGH A CRITICAL ADAPTATION OF MAXINE HONG KINGSTON'S NOVEL THE WOMAN WARRIOR

by

Julia Valentina Salvador

APPROVED FOR THE DEPARTMENT OF COMMUNICATION STUDIES

SAN JOSÉ STATE UNIVERSITY

August 2010

Dr. Matthew Spangler

Department of Communication Studies

Dr. Deanna Fassett

Department of Communication Studies

Dr. David Terry

Department of Communication Studies 


\begin{abstract}
QUEERING HEGEMONIES OF GENDER AND CULTURAL IDENTITY THROUGH A CRITICAL ADAPTATION OF MAXINE HONG KINGSTON'S NOVEL THE WOMAN WARRIOR
\end{abstract}

by Julia Valentina Salvador

This thesis explores hegemonic discourses associated with the constructs of gender, culture, and transglobal migration from China to the United States and how these discourses might be made visible, resisted, internalized, reappropriated, and queered through live performance. This thesis used the methodology of critical adaptation and adapted Maxine Hong Kingston's novel The Woman Warrior (1976) into a one-woman performance that explored hegemonic social structures of gender, culture, and transglobal migration and the ways in which identity is constructed and performed. Through a critical adaptation and performance of literature, this thesis reflects, expands, and raises some of the nuanced issues of transglobal identity that move between structures of marginality and empowerment. The timeline of this thesis project expanded over the course of a year and a half. The spring semester in 2009 was dedicated to adapting Maxine Hong Kingston's novel The Woman Warrior. In the beginning months of the fall of 2009 , the prospectus was written and the performance was rehearsed. In the month of October, the prospectus defense was held and of the performance was premiered on the evenings of November $5^{\text {th }}, 6^{\text {th }}$, and $7^{\text {th }}$ in Hugh Gillis Hall room 231 at San José State University. And lastly, in the spring semester of 2010, the analytical portion was completed. 


\section{ACKNOWLEDGEMENTS}

Thank you, Dr. Spangler. It is an honor having you as my advisor and my mentor. I am forever grateful for your unremitting guidance, wisdom, and everything you have taught me. I deeply admire you as a scholar, as a teacher, as an artist, and as a friend.

Thank you, Dr. Fassett and Dr. Terry. It is an honor having you on my committee. Your mentorship, support, and thought provoking questions inspire me to be a better writer and scholar.

Thank you, members of the Department of Communication Studies. It is an honor being part of this community. I will forever cherish the memories.

Thank you, San José State University. For all the faculty, staff, and reviewers who have contributed to the success of thesis work.

Thank you, my Graduate School and GTA Cohort. Thank you for the life long friendships.

Lastly, thank you dear dad and mom, family, friends, and loved ones. I could not have done this without your wisdom, guidance, love, and support. 


\section{TABLE OF CONTENTS}

Chapter One: Introduction............................................

Chapter Two: Literature Review...........................................9

Chapter Three: Methodology: Critical Adaptation of Literature...................32

Chapter Four: Discussion............................................43

Blocking .......................................................46

Music..........................................................49

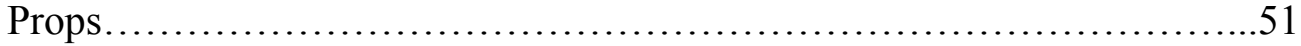

Scene I: no name woman......................................5

Scene II: MADSWORDSWOMAN \& Scene III: china doll, useless girl....58

Scene IV: Warrior Lessons Magazine Rehab..........................64

Scene V: You Better Talk.........................................67

Scene VI: Tightly Unbound......................................71

Chapter Five: Closing Thoughts....................................... 73

The Woman Warrior Script............................................... 80

References......................................................... 120 


\section{CHAPTER ONE: INTRODUCTION}

Chinese-Americans, when you try to understand what things in you are Chinese, how do you separate what is peculiar to childhood, to poverty, insanities, one family, your mother who marked your growing up with stories, from what is Chinese? What is Chinese tradition and what are the movies? Those of us in the first American generations have had to figure out how the invisible world the immigrants built around our childhoods fits in solid America. (Hong Kingston, 1975, p. 5)

Before and after my initial reading of Maxine Hong Kingston's novel The Woman Warrior during my junior year in high school, I constantly struggled over questions about the intersectionalities of race, gender, culture, sexuality, and identity construction. After reading The Woman Warrior, I began to see myself and these constructions in different ways than I had before. My changing perspectives surfaced an uncomfortable, challenging, and risky condition. As a child of immigrant parents from China and Portugal, I grappled with trying to understand and reconcile what in me is "Chinese," "Portuguese," "American," and "woman," as if these words can be located on my body, like an anatomically labeled dummy's manual, sectioned off and bordered. My mapped body reads as follows: my slanted eyes and jet black hair are Chinese, my olive toned skin and my Roman style nose are Portuguese, my red high heels and tongue are American, and lastly, my painted face and curved body are woman. Like a paper doll, I produced, performed, and preserved these lucid articulations of borders on my body. Like a border patrol officer, I delineated what performances on and of my body were allowable and forbidden, safe and unsafe. Ultimately, I drew off of them for standard discourses of identity. When I performed the ubiquitous stereotypes of what is Chinese, Portuguese, American, and woman, my body strategically remained unquestioned and unnoticed, and I reveled in the confines of normalcy. 
While these stereotypical molds were easy and legitimatized within the hegemonic discourses associated with the constructs of identity, my participation and performance with them were violent acts on my body. I soon learned that when I questioned and broke the image repertoire and queered the markers of legitimatized identity, I was in peril. I asked my high school friends, "Huh...you know, when I was little, I only saw images of boys and girls kissing. Isn't that weird?" They replied with a confused smirk, "Uh no! Why, are you gay?” Whip, slash, I am punished. My mother said, “Julia, what do you think you are doing? Don't draw attention to yourself in that way; people might think you are easy." Whip, slash, I am bound. In elementary school my classmates yelled, "Hey Julia, what are we saying, CHING CHONG DING DONG?" I yell back, "I don't know; I'm not even Chinese!" Whip, slash, I am ashamed. The four years of my high school experience were the most difficult as I became more aware and uncomfortable with the tensions of identity that I felt within myself.

The moments where I began to question and challenge the hegemonic social structures of identity, I began to queer my identity and my relationship to those structures of power. For E. Patrick Johnson, to queer is to "resist or elide categorization, to disavow binaries and to proffer potentially productive modes of resistance against hegemonic structures of power" (Johnson, 2008, p.166). In those moments of queering, I began to question the ways in which I participated in the social constructs of identity, in particular culture and gender, in hopes of opening up spaces for less rigid and singular identities. However, given that schoolyard politics were beyond callousness, my inquiries came with a price. I was ridiculed and disciplined not only by my peers and family, but by 
myself when I challenged and questioned my socialization. When my public performances conformed to the expectations of what it meant to be a Chinese, Portuguese, American woman, I felt bound, confined, and disoriented. The pressures of having to participate in the social structures of gender and cultural identity construction has led me to bifurcate, compartmentalize, and separate my identity into facets, as if it should be easy to understand, consume, and digest. Because identity is a process, not a single, coherent manifestation, it is often not easily understood. Therefore, the complicated in-between narratives of identity are often not legitimized and are hence pushed to the margins of social and cultural discourse.

After re-visiting my favorite book as a graduate student, my orientation towards the text changed. I saw Hong Kingston's novel as something more than an articulation of memoirs; rather it functioned for me as a collection of tactical responses to hegemonic oppressive ideologies of identity construction and articulation. It is a tactical response that critically speaks back to a referential and historical event of gender and cultural politics. It speaks back to historical events that are often positioned as canonical and natural or unchangeable. The novel functions as an agent of reappropriating hegemonic discourses of identity. As a result of reading this novel, I better understand how I might push back and challenge the constant need to bifurcate my identity. In Hong Kingston's novel, there are moments where the narrator challenges and highlights the power structures of marginality by making the invisible visible and by complicating the negotiations and tensions of identity construction, which, for me, are moments of empowerment. 
Though the novel functions in my thesis as an empowering source of adaptation, it has also been subject of much criticism. Since its publication in 1975, Hong Kingston's novel has been accused for a "misrepresentation of cultural truth" (Yuan, 2001, p. 199) by its Chinese and Chinese-American readership as well as for a lack of coherency and traditional storylines by hegemonic American audiences. Critics of Hong Kingston say she exercises the "Amy Tan phenomenon" whereby she "mediates and repackages the Orient for a white readership" by exoticizing the Chinese Other, or so the argument goes (Yuan, 2001, p. 199). In addition, Yuan (2001) reports that opponents, primarily the white-readership of the novel, argue that Hong Kingston's memoir is difficult to understand because of the muddled talismanic narratives and seemingly nonautobiographical accounts. Opponents argue that the novel problematically attempts to negotiate several discourses simultaneously in which the Western autobiography, Chinese-American tradition of assimilation narratives, and Chinese patriarchal tradition work against each other and produce contradictions in the storyline (Yuan, 2001).

While Hong Kingston frames the novel as a series of memoirs, which reveal some experiences surrounding her lifetime, it is primarily a work of fiction, in which her main goal is to articulate an account of growing up having to negotiate the social constructs of gender and race. Because the novel is framed as a work of fiction, Hong Kingston can tactically blur the lines between truth and fantasy, and in doing so, question what is "truth" in relationship to autobiographical accounts, specifically that of a non-white minority group. However, I argue that Hong Kingston deliberately and wittingly writes in contradictions as a means of cultural transgression and tactically responds to 
oppression and marginalization. In the novel, Hong Kingston refuses to create stagnant realities or generalizable accounts of gender and race: rather, the novel should be seen as multilayered, complex, and multi-dimensional, like issues of gender and race themselves. In the novel's intermingling of linear narratives with magic realism, Hong Kingston complicates notions of identity construction as the narrator struggles to find meaning in the nuanced liminal spaces between gender and transglobal identity. As a daughter of immigrant diasporic parents, her cultural community was pushed to the margins of society, Othered for their differences in language, customs, and appearances. Although it appeared clear to outsiders that she was "different," it was difficult to find what in her was Chinese, American, and woman. She argues through her novel that the structures of identity inform one another, creating new spaces for identity. Places in the text when Hong Kingston tactically responds to colonialistic strategies of control by reappropriating and altering those strategies into performances of tactical mimicry, as a means to displace and shatter that control.

But as Della Pollock (2008) might point out, Hong Kingston's subversive acts are, in fact, authorized by previous tellings, previous stories. Her tactical literacy actions are not super agents, but rather products of a particular space and time. Therefore, Hong Kingston's ability to respond to her environment subversively and tactically is sanctioned by the notion that performative culture and canonical histories are reliant on the "various repetitions that threaten its stability and disrupt the authority of origins or first stories, foundational premises, original referents" (Pollock, 2008, p.122). It is through 
restor[y]ing grand narratives that one can reenact, reconfigure, and rethink performance, culture, and identities.

For my thesis, I aimed to investigate a particular strategy of negotiating ChineseAmerican transcultural and gendered identities through The Woman Warrior. I asked in what ways can a Chinese-American woman navigate her own subjectivity to find agency and empowerment in what de Certeau would call "tactical" responses to hegemonic power structures that push her to the margins? de Certeau's notion of "tactical" is "a calculated action... an art of the weak...operating in isolated actions" (de Certeau, 1984, p. 37). The tactical might function as a subversive act in which one can challenge and reappropriate hegemonic structures of dominance and power. However, I also asked in what ways might the tactical function to sustain and reinforce hegemonic structures of control? I also define hegemony in this thesis as the ways in which particular dominant ideologies are established, reproduced, and sustained through the use of common, widely accepted discourses and social structures.

What makes this research compelling, critical, and warranted is the nuanced investigation that pushes and broadens the limiting and often problematic constructions of what it means to be a Chinese-American woman. My research and paradigmatic perspective embodies a critique that examines and explores the ways in which discursive texts of femininity and transcultural identity are circumscribed on the body, as a means of deepening and complicating our understanding of identity construction. I adapted, wrote, scripted, directed, and performed Hong Kingston's novel The Woman Warrior through the methodology of live performance, as a means of rewriting the performative and 
discursive constructs of identity. Rather than using transcribed interviews or ethnographic field notes from Chinese-American women, my choice to adapt a fictive novel for live performance is one that strives to challenge what is "truth" in relationship to the articulation of identity construction. My use of the fictitious novel does not surrender itself to a world of total imagination and dissonance to "real" life stories of Chinese American women, rather it opens up alternative avenues to explore these issues. I regard Hong Kingston's work of fiction, which explores the issues and challenges of negotiating transcultural and gendered identities, as a compelling representation of those concerns. The novel draws upon the challenges and issues of the social world, though it is framed as a fictive account. Therefore, within the fictitious novel, the concern is not with demarcating narratives of truth for generalizability purposes, but rather, recognizing what the possibilities are in relationship to what is considered true of identities. My methodological choice of a critical adaptation draws upon specific ethical, respectful, and critical concerns that will help guide my approach. For me, fiction is open for scrutiny and critical analysis in ways that are different than a strictly autobiographical story would be. In Hong Kingston's novel, I can analyze, critique, and explore the arguments, themes, and social structures at play without having to call out or satirize a personal narrative. In this case, the ambiguous and nameless narrator allows me to implicate the power structures and her participation within those structures in ways that are less concerned with being disparaging to a storyteller in a vulnerable moment of story sharing. 
For my thesis, I am specifically interested in critiquing hegemonic discourses associated with the constructs of gender, culture, and transglobal migration from China to the United States and how these discourses might be made visible, resisted, internalized, reappropriated, and queered through live performance, using the methodology of a critical adaptation and performance of Maxine Hong Kingston's novel The Woman Warrior. My thesis draws upon a critical paradigmatic perspective in that my critical adaptation and performance seeks to reflect, expand, and surface the nuanced issues of transglobal identity that move between structures of marginality and empowerment. My critical adaptation explores the ways in which rearticulations of past histories, stories, and narratives can enter into the realms of displacing those narratives and "finding the unstable aesthetics of repetition an ethics and politics of possibility; and ultimately then shifts culture itself into the subjective register of what if, as if, could be" (Pollock, 2008, p. 122). The performance beseeches a critical exploration of the negotiations between various cultural and personal identity constructions in ways that highlight the narrator's complicity in her own subjugation as well as her subversive responses. The script and performance showcase moments in the narrator's life where she participates with marginalizing structures as well as empowering subversive transgressions, highlighting where those moments intersect and diverge from one another. The performance and directorial choices seek to create spaces for living between the ambiguous borderlands of transcultural and gendered identities that are often pushed to the margins of society. 


\section{CHAPTER TWO: LITERATURE REVIEW}

The ways in which the social and cultural scripts of gender, culture, and transglobal migration are circumscribed on the body in often confining and limiting means are what prompted this research. Through my investigation, I want to revisit and reconsider the categories of Chinese-American gendered identities to destabilize their pervasive homogenous branding by adapting and performing a narrative of growing up as

a Chinese American woman that explores the narrator's subjectivity in relationship to oppression and liberation. Through nuanced and deep investigation, I can explore avenues that move beyond the site of marginality, and examine how marginal groups rearticulate and reappropriate power. The themes that I am seeking to explore are how a particular Chinese-American cultural identity is performed along paradigms of power in Maxine Hong Kingston's novel The Woman Warrior. I ask: how does subjectivity in liminal spaces find agencies of power and what are the political implications of doing so? In other words, under what conditions do the tactics that reappropriate that power serve as a means for exposing the institutional strategies of marginality and when might they further oppress and subjugate marginalized groups?

The theories and paradigms that my research draws upon aim to surface and shed light on the on-going conversations and investigations of the ways in which performance intersects with notions of storytelling, power, identity, agency, and ethics to provide a nuanced narrative about troubling identity construction and moving beyond marginality. I begin by exploring the ways in which hegemonic structures and discourses of power are exercised through the constructs of gendered and cultural identities and the ways in 
which those identities are shape and reshaped on a personal level through the body. Specifically I ask: how can performance, storytelling, and grand narratives of identity construction be challenged, reappropriated, and queered? I turn to Ruth and Michael Bowman's investigation of the historical and political efficacies surrounding performances of literature, and then I explore Edward Said's discussion of storytelling as a compelling site for empowering authorship of culture. I ask: In order to carve out subversive narratives, how does a performance of storytelling create a space that problematizes the allure and cache of grand narratives? Through the lens of storytelling, I explore both Ravina Aggarwal and Rustom Bharucha's investigations of performances of cultural identity constructed in relation to paradigms of power, as well as Judith Butler's critique of performances of gendered bodies.

Then I move on to explore how transgression of identity constructs can be a means of tactical mimicry. More explicitly, Michel de Certeau's and Victor Turner's theories on tactics and liminoid phenomena respectively carve out performative spaces that not only challenge the status quo, but offer moments for transgressing the binding hegemonic constructions and discourses of identity, providing my thesis with discussions and examples of theoretical possibilities for empowerment. In addition, I look to Homi Bhabha's and Gloria Anzaldúa's work on performance of mimicry and the ways in which mimicry can become a means of reappropriation and transgression of cultural and gendered identities.

However, as I will discuss, mimicry can cut both ways. It can serve as an avenue for liberation as well as continual subjugation. My survey of Fantz Fanon's, Chinua 
Achebe's, and Toni Morrison's responses to the performance of mimicry as a possible oppressive strategy highlights the complexities of empowerment and the ways in which mimicry can, in fact, operate as a strategy for marginality. Given that mimicry has the potential to be both a tactical transgression and a strategic manifestation of power in relationship to the performance of identity, it must be considered in ethical contexts. Dwight Conquergood's analysis of performance as a moral act critically surfaces the ethics of performing representations of identity and the ways in which a performer should always strive for a "dialogic" performance. Finally, Susan Headicke's study of the French performance Un Voyage Pas Comme Les Autres Sur Les Chemins De L'Exil (2002) is exemplary in that it showcases the immeasurable pedagogical efficacy that performance has as a site for critical engagement. Together these sources allow me to navigate the spaces between Chinese-American and gendered identities in nuanced and complex ways.

Performances of literature can be responses to challenge and call into question oppressive ideologies. In other words, approaching Hong Kingston's novel, The Woman Warrior, through a performance of literature, I can reinterpret, support, and challenge the grand narratives of the text itself as well as the performativity of identity that constitutes knowledge and legitimatizes realities. The use of performance as a means of investigation frames my research in a way that recognizes how our social realities, lives, and identities "are structured according to repeated and socially sanctioned modes of behavior raising the possibility that all human activity could potentially be considered as 'performance"' (Carlson, 1996, p. 4). In other words, performance has the capacity to 
make visible the social scripts that we follow and suggest the ways in which we might change them. Once we make the social scripts of gender and culture visible, we make the possibility of altering and challenging those scripts possible. A live performance has the potential to draw attention to the ways in which we can alter the social constructions of our identity in more nuanced and transitory ways. As such, a performance of literature might carve out spaces for the contestation and exploration of the social world in which we live through specific embodied acts.

Performance is an act of resistance, blurring boundaries, and creating spaces for empowerment. As Richard Schechner says of performance studies as a whole, "performance studies resists fixed definitions. Performance studies does not value purity... as it is open, multivocal, and self-contradictory...therefore, any call for a 'unified field' is, in my view, a misunderstanding of the very fluidity and playfulness fundamental to performance studies" (Schechner, 2002, p. 22). This form of border-crossing creates new spaces for discourse, interpretation, and meaning-making that requires constant rethinking, reshaping, and reevaluating in trying to make sense of the world and political bodies around us. Bowman and Bowman both agree that the positionality of performance studies is empowering because it moves between, in, and out of structures, critically surfacing different perspectives, understandings, and implications about the construction of meaning making and identity.

Performance of identity draws on structures of performativity. As Richard Schechner defines it, "Performativity points to a variety of topics, among them the construction of social reality including gender and race, the restored behavior quality of 
performances, and the complex relationship of performance practice to performance theory" (Schechner, 2002, p. 123). At the heart of performance lies the ability to "recognize, analyze, and theorize the convergence and collapse of clearly demarcated realities, hierarchies, and categories" (p. 131). As a result, performance can be a vehicle of agency in relationship to structures of power. Performance is an instrument that reconstructs, queers, questions, and complicates the social constructions of identities. In other words, performance is a manifestation of the ways in which social realities imbue art and art imbues social realities.

Therefore, the reflexive relationship between art, life, and performance highlights the ways in which all three are not natural occurrences, but rather are socially constructed to privilege, uphold, and establish a particular ideology, an ideology that rejects ambiguity and difference. Being able to identify certain oppressive social constructions enables the ability to rewrite social behaviors, attitudes, and ideologies attributed to identity, and hence, engage with performances as tactical to move into spaces in which the authorization of nuanced identities is possible.

Both Turner's "social drama" model and Baudrillard's "simulation" model (Schechner, 2002) note a fluid relationship between the aesthetic theatrical practice and the social/daily practice. "The visible actions of any given social drama are informed, shaped, and guided by aesthetic principles and performance/rhetorical devices. Reciprocally, a culture's visible aesthetic practices are informed, shaped and guided by the processes of social interaction" (Schechner, 2002, p. 76). Therefore, the reciprocal relationship between aesthetic practices and social practices inform one another. Like 
authoring different narratives in storytelling, engaging performativity in different ways garners opportunities to challenge and disrupt hegemonic articulations of identity that harmfully limit and confine the body. The process of performance demands spaces for ambiguity and fluidity in relationship to identity construction. The performance of identity is, thus, the process of creating a self, an empowering and embodied act of authorship and control.

Together the triage of literature, adaptation, and performance becomes a meaningful process of studying and exploring rearticulation, reappropriation, and empowerment of nuanced, non-essentialized identities. As Ruth and Michael Bowman state, performances of literature are interested in "boundary-crossing [as an] inter/antidisciplinarian, thus performance studies might borrow, or 'poach' its theory from anywhere as it tries to make do within the confines of academe" (Bowman and Bowman, 2006, p. 218). In this sense, performances of literature have the capacity to identify existing pervasive strategies of power and then reshape them to create narratives that emphasize fluidity and ambiguity.

As the aim of this thesis manifested in a public act of storytelling, I find it useful to unpack the significance of this term to better understand its pervasive clout as a mechanism to assert power, authorship, realities, and identities. Edward Said (1993) states that stories and narratives have always functioned as sites of empowerment because not only do they transcend cultures, but they are powerful forms of expression. The articulation of stories, from the art of oral tradition to books, films, theatre, and performances, have always had the ability to captivate, compel, and create meaning 
between audiences and storytellers, as well as construct identities of speaker and listener. In addition, in a number of cultures, stories have more crucially acted as opportunities and "method[s] colonized people use to assert their own identity and the existence of their own history" (Said, 1993, p. xiii). Stories can be responses to hegemonic grand narratives that privilege particular realities and delegitimize others; therefore, the ability to critically write, rewrite, add, subtract, combine, and reform stories is an assertion of power. A political form of authorship is to take a text that harms and sustains the peripheral existence of the "Other" and alter it to assert empowerment and legitimacy as a means of subversion. Narrating "culture is a source of identity, and a rather combative one at that, as we see in recent 'returns' to culture and tradition" (Said, 1993, p. xiii). These "returns" to tradition challenge what is and is not legitimate constructions of identity.

An adaptation of Hong Kingston's novel, for example, lends itself to challenge my cultural traditions in that I employ ambiguity, playfulness, and a sense of irony to explore the socio-political constructs of gender and race. In the act of altering a literary work, that of Hong Kingston's novel, and juxtaposing it with contrasting, exaggerated, and different issues and themes, my adaptation seeks to challenge traditional narrations of culture as identity formation. This performance might highlight the fact that identity is never natural, rather it is an embodied act, an act that can be made and remade. Lastly, if narrating culture, as Said says, "is a sort of theater where various political and ideological causes engage one another" (p. xiii), then the act of storytelling surfaces the ability to 
play, try out, challenge, and reconstruct identity of culture in ways that might be liberating and empowering.

Ravina Aggarwal's work on performing identity beyond lines of control connects performance and cultural identity in meaningful ways. Aggarwal investigates the ways in which identity is constructed along lines of marginality through performance. Cultural identities are "cultural performances... [which] frame...the drama of life as mimicked and exhibited" (Aggarwal, 2004, p. 16). Performance does not act as a "passive mirror of society, rather it is often a critique, direct, or veiled, of the social life it grows out of, an evaluation (with lively possibilities of rejection) of the way society handles history" (p. 16). Performance that materializes performativity not only unmasks the strategies of control, but also makes possible the power of constructing and reconstructing new identities.

Like Aggarwal, Rustom Bharucha also examines the tensions among representations of cultural identity, performativity, and performance in his book The Politics of Cultural Practice (2000), though Bharucha argues that language itself is an act of performativity that has political implications for cultural constructions of identity. He illustrates the performativity of language through the competing implications of the terms "multicultural," "bicultural," and "transcultural." For Bharucha, the term "transcultural" is a discursive means of identification that acknowledges identity to be transitory, fluid, and existing in the liminal borderlands of cultural identity. In my thesis, I consciously choose not to use the terms "bicultural" or "multicultural" identity because, following Bharucha, these terms limit and problematically reproduce essentialist identities. 
"Bicultural," for instance, assumes polar opposites and creates a binary between identities, inhibiting movement. Additionally, as Bharucha argues, the term "multicultural" is an oppressive strategy used by the state to appear sensitive to different cultural groups, though often superficially. "Multiculturalism is a disavowed, inverted, self-referential form of racism, 'racism with a distance'..." (Bharucha, 2000, p. 34) that has historically oppressed non-white groups as an institutionalized way of essentializing cultural identities and meeting quotas (Bharucha, 2000). "Transcultural" does not assume a fixed, stagnant articulation of identity construction; rather it is open to ambiguity, change, and plurality.

Like Bharucha's work on constitutive language and its relationship to identity construction, Judith Butler (1990) similarly discusses the problematic effect of naturalizing identity construction in relationship to gender politics. Butler is concerned with the ways in which language and performativity inscribe bodies with compulsory heteronormativity. Her notion of troubling the social constructions of gender through language allows for the plurality of representation and exposes the phallogocentrism and compulsory heterosexuality with which language binds social bodies. Through reenvisioning, revolutionizing, and altering perceptions of politicized discourse, Butler works to expose the problematic categories of sex and gender imposed on bodies that appear to be natural, thus sustaining marginality. Butler's use of a genealogy investigation unmasks, as she puts it, "the political stakes in designating an origin and cause to identity categories that are in fact the effects of institutions, practices, and discourses with multiple and diffuse points of origin" (Butler, 1990, p. xxxi). The poetics 
of gender also imprison bodies to fit the institutional needs of clear, distinct definitions of identity that sustain heteronormativity and phallogocentrism. Bodies that are unintelligible because they challenge gender roles and definitions are either marginalized or disciplined into "normalcy." Challenging the poetics of language and altering the performativity of identity in relationship to gender disrupts the comfort in naming, placing, and labeling fixed identity construction. Through a heuristic process, Butler seeks to move away from the margins into a space where the complexities of gender can move freely in discourses that fight against and refrain from the compulsory heterosexuality and phallogocentrism to revolutionize the feminist gender critique.

Butler starts with the representation and subject of "women" to point out that the word "women" is no longer an acceptable representation for political liberation because it is not only inadequate, but it also misrepresents "women" as a homogenous, coherent group, with a common identity. The use of the term "women" is an act of power and control that regulates, limits, and controls identity. Butler encourages us not only to think about how "women" might become more fully represented in language and politics, but that the "very category of 'women' itself, the subject of feminism, is produced and restrained by the very structures of power through which emancipation is sought" (p. 4). As the discourse of "women" is decontextualized of race, class, ethnicity, among a number of other things, it imposes colonization on non-Western cultures who do not support or adopt Western notions of feminism and oppression (Butler, 1990). Therefore, "the task is not to refuse representational politics, [but rather]...to formulate within a constituted frame a critique of the categories of identity that contemporary juridical 
structures engender, naturalize, and immobilize" (p.7). By doing so, we can challenge the hegemonic construction of gender and interrupt it with counter hegemonic nuanced experiences, rather than stagnant naturalized definitions.

Somewhat like Butler's articulation of language as a means of opening up spaces for empowerment, de Certeau, too, sees language as a mechanism of subversion and reappropriation. Though, in comparison to Butler, de Certeau places greater emphasis on individual agency. In his book, The Practice of Everyday Life, de Certeau (1984) uses the example of walking around New York City as a metaphor for reshaping language as a means of creating and recreating identities around and within existing structures of power. de Certeau not only implicates the audience for participation in the construction of binding structures, but also he sheds light on the possibility of navigating the city in potentially liberating and subversive ways as well. The materials of subversion are not infinite, rather they are limited by what is already in place. Therefore, the "pedestrian speech acts" (de Certeau, 1984), as de Certeau calls them, are appropriations of language that go beyond the fixed constructed order to a number of unwritten and unspoken possibilities of transgression and transformation of binding language. This borderland existence becomes a "liberated space, functioning to articulate a second, [more] poetic" (p.105) and nuanced means of creating identities. Finally, de Certeau implores us to challenge and contest what is unnaturally framed as natural, such as language and the performativity of identities, because there is always a legend on a map that articulates "what is to be read, but [more importantly] what can be read" (p. 106), or as he states later through the use of his central metaphor, "a great city [can be] built according to all 
the rules of architecture and then suddenly shaken by a force that defies all calculation" (p. 110). The reappropriation and change from within the structure moves marginality to the center as a means of empowerment from within.

Throughout my critical adaptation performance, my body acts as a means to communicate the more poetic and alternative meaning that is so central to de Certeau. For example, during a scene in the novel as well as my adaptation, the narrator confesses to bullying and torturing a younger Chinese girl at school who does not speak English or participate in the conventional structures of femininity common in the United States. The younger Chinese girl reminds the narrator of herself, who was also possibly tormented as well for refusing to speak English and not emulating "American" standards of hegemonic beauty. In the performance, through my body, I seek to communicate that while the narrator is torturing the young girl, she is, in fact, disciplining herself by embodying both the narrator and the young girl. The narrator takes on a role of mimicry as a strategy to marginalize and harm others, as well as to harm herself. My direct gaze onto the audience during that scene seeks to draw attention to the audience's own participation in marginalizing acts. At that moment, the text appears to say that the oppressor and the oppressed are separate from one another; however, in the performance, the audience, the narrator, the young girl, and the performer are all drawn together, complicating the notion of performativity in relationship to oppressed, oppressor, and participation in those power structures. The strategies of performativity as control and oppression must be recognized by us to reject these oppressions and to reshape and challenge the social constructions of identity. 
Victor Turner's (1982) and Michel de Certeau's (1984) work on liminoid borderlands and appropriation of language informs my research to better understand the complexities of existing on the margins and rearticulating power structures. Turner's definition of liminoid is the ambiguous space that allows for the movement in and between structures, such as bifurcated identities. "Liminoid phenomena may be collective but are more characteristically individual... and more idiosyncratic, quirky, to be generated by specific individuals" (Turner, 1982, p. 54). Liminality is a psychological separation from the status quo, opening up possibilities for queering "grand narratives of identity." Liminoid performances create spaces where critical and experimental thought are of choice rather than of obligation. The distinction between choice and obligation critically signifies the consciousness and intentionality to make, remake, challenge, or support a particular performance of identity, in my case of gender and culture, as a purposeful and political one. Performance in the liminoid centers on and draws meaning from idiosyncratic and plural experiments. This positionality "often [surfaces] social critiques or even revolutionary manifestos...exposing the injustices, inefficiencies, and immoralities of the mainstream economic and political structures and organizations" ( $\mathrm{p}$. 54-55). The exposure of institutionalized strategies of fixed identities paired with the choice to accost them becomes a critical moment of empowerment and liberty.

A specific example of liminality in Hong Kingston's novel, which I problematize in different ways in my adaptation, is the subversive narratives of feminist critique and empowerment. In the novel, the narrator often criticizes the symbolic status and ideology of feminism, framing them as collectively driven by cultural structures. The narrator 
shares a story of feet binding as an act of subjugation of women in China and of a warrior woman, Fa Mulan, who draws her power from her performance of masculinity. In my adaptation, I trouble this notion of culture tied to empowerment and disempowerment by questioning the strategic discourses of gender in relationship to femininity, specifically the pervasive narratives of freedom in "America" articulated in mundane conversations and cultural biases shared in the novel. Including some of my own writing, I adapt a number of magazine titles aimed for American women readers that bind and control the political bodies of women that necessitate the performance of "beautiful," as a means of questioning and challenging freedom and empowerment. In my adaptation, I respond to the novel and create an alternative, liminoid narrative that questions and implicates the audience's participation in performing self, gender, and culture. My thesis performance not only aims to complicate an understanding of the self, but it also seeks to call the audience into social action, compelling them to view the performance as more than an aesthetically pleasing show, but rather as an opportunity to challenge the constructs of identity.

Homi Bhabha's research on cultural identity representations and the discursive use of mimicry serves as a form of agency from oppressive structures. Bhabha's use of mimicry refers to marginalized groups who employ tactical responses to oppressive colonial powers by commandeering the former means of marginalization and reappropriating them to move into spaces of empowerment. Bhabha states:

Mimicry emerges as the representation of a difference that is itself a process of disavowal... which 'appropriates' the Other as it visualizes power...it is also the sign of the inappropriate, however, a difference or recalcitrance which coheres the dominant strategic function of colonial 
power, intensifies surveillance and poses an immanent threat to both 'normalized' knowledge and disciplinary powers. (Bhabha, 1994, p. 122)

Mimicry not only becomes a subversive response to critique power, but it can also create the possibility to carve out spaces of empowerment to manifest. Mimicry names, draws attention to, and threatens the hegemony and structural integrity of power that marginalizes bodies of difference. Mimicry, as a tactical tool, necessitates questioning pervasive "normalized" definitions and behaviors in relationship to identity.

Like Bhabha and Hong Kingston, Anzaldúa uses mimicry tactically to transgress away from marginalization and towards a reappropriation of identity construction that is expansive and empowering. The borders of language, sex, sexuality, gender, and transcultural identities controlled and disciplined Anzaldúa's construction of self. Anzaldua's notion of self was fraught with struggle as she tried to navigate the landscapes of what it meant to be Chicana, American, indigenous, and queer. Her body was displaced, not necessarily in a topographical sense, but rather in a hegemonic structural one. Her refugee body and identity worked against the notion that identity must be intelligible, marked, easily understood, and consumable. In the confines of the borders, her identities must be normalized although they were alien to herself.

Anzaldúa specifically used language as a means to reappropriate her identity as a mestiza by mimicking the ways in which it formerly hurt her. According to Anzaldúa, la mestiza identity exists in strife, dualism, tension, and plurality that is ambiguous and ever changing, open to the possibility of difference, otherness, and rearticulation. La mestiza is constantly in "a mental and emotional state of perplexity...plagued by psychic restlessness" (Anzaldúa, 1987, p. 100). La mestiza is always evolving and questioning 
social constructions of identity in ways that liberate performativity. She uses her tongue as a sharp serpent that cuts across language borders and freely writes in Spanish without translations because her identity does not need to be intelligible, marked, and consumed. "From this racial, ideological, cultural and biological cross-pollinization, an 'alien' consciousness is presently in the making--a new mestiza consciousness, una conciencia de mujer. It is a consciousness of the Borderlands" (Anzaldúa, 1987, p. 99). Her performative move to the borderlands through mimicry allows room for the ambiguity of identity. Anzaldúa's work lends itself specifically to mimicry because of the ways in which she names the strategic oppression of language, gender, and identity and disavows them to create a tactical identity that is ambiguous and exists outside any means of borders. Her mestiza identity, as she puts it, "copes by developing a tolerance for contradictions, a tolerance for ambiguity...rigidity means death” (Anzaldúa, 1987, p. 101). She simultaneously participates in the structures that marginalize her and challenges them as well.

In a twist on Bhabha's and Anzaldúa's usage of mimicry as a tactic, Chinua Achebe and Toni Morrison point out that mimicry can cut both ways. In their novels, these authors show how mimicry serves not as a tactic, but rather as a strategy to sustain oppressive structures and how those strategic structures are further appropriated by "the marginalized" as a means to hurt their own and sustain their subordinate state of being. In Things Fall Apart (1959), Achebe illustrates mimicry as a strategy to sustain marginality. The novel is set in the 1890s and exposes the political and social abuses of the British colonizers on the people of the Igbo village in Nigeria. Specifically, in the 
novel, the character Enoch, the son of a Nigerian village priest, converts to Christianity, becomes a religious zealot, and embraces the colonial rhetoric of Nigerian inferiority. He takes it upon himself to commit oppressive crimes against his clan's people as a means of sacrament for his physical association with them. During an annual ceremony of honoring the earth deities, Enoch rips off the mask of one of the earth deities, a seriously disrespectful act. Because Enoch's physical association with the marginalized exists through a racialized body, the psychological disassociation through mimicry not only becomes necessary, but desired to further oppress and marginalize his clan's people and by extension himself. Enoch engaged in both physical and emotional strategic mimicry to sustain institutionalized racism. Therefore, Enoch reprimanded and desecrated his clan's cultural ideologies and ways of being, like the colonizers did, as a strategy to assert and sustain power whilst disempowering them. As Franz Fanon puts it:

Every effort is made to bring the colonized person to admit the inferiority of his culture which has been transformed into instinctive patterns of behavior, to recognize the unreality of his nation, and, in the last extreme, the confused and imperfect character of his own biological structure. (Fanon, 1963, p. 236)

In this sense, the colonized person validates and bears out the oppressive ideologies of the colonizers in such a way as to sustain marginality. This theory is also demonstrated in the The Woman Warrior, specifically between the main character and a younger Chinese girl. After moving from China to the United States, the narrator internalizes the racist discourses of her cultural inferiority and exemplifies it by reiterating the oppressive hegemonic discourse on another Chinese girl. 
Similarly, Morrison's novel The Bluest Eye (1970) exemplifies mimicry as a marginalizing and culturally detrimental act. A number of characters, throughout the book, painfully move through daily activities that reinforce cultural and political attitudes of racial subordination. The novel's main character Pecola, suffers the abuses of mimicry through the hands of her family and her community because she is a physical symbol of their marginality. Pecola's greatest desires are to be loved and to be beautiful, specifically to have blue eyes, both of which are impossible because both her family and community, including herself, recognize and regard her as a symbol of black ugliness, an ideology pushed upon her by hegemonic discourses of white beauty. Pecola also becomes a scapegoat for which her family and community internalize their own cultural inferiority and redirect it onto Pecola, a young defenseless girl. Pecola's internalization of cultural inferiority steams from external and internal forces of mimicry of hegemonic ideologies of beauty and race. Pecola successfully internalizes and regards the abusive acts of mimicry as preordained because of her inferiority and desire for things she cannot have. Pecola believes that she is undeserving of love because of her marginality. At the end of the novel, Pecola is rendered into a state of insanity, further pushed to the margins of society.

This analysis of mimicry in the works of Bhabha, Anzaldúa, Fanon, Achebe, and Morrison informs my own analysis of Hong Kingston's novel as I seek to expose strategies and tactics that intersect with structures of power. I ask: in what ways do the narratives in the novel sustain the structures of power and in what ways are they challenged? The novel is written from a positionality of specificity, uniqueness, 
ambiguity, playfulness, and a sense of irony. Hong Kingston seeks to implicate, confront, and critique "Chinese" culture, "Chinese-American" culture, and "American" culture with examples of mimicry as both strategy and tactic in order to explore new constructions of self. Those explorations sometimes sustain structures of power while others disassemble them. An example of mimicry deployed as both a strategy and a tactic within both Hong Kingston's novel and my adaptation occurs in the opening scene. In this scene, the narrator, who remains a nameless woman, shares a story that her mother shared with her about infidelity and death. The story is about her aunt who becomes pregnant outside of marriage and, as a result, kills herself and the baby in the family well. The telling of the story is an act of strategic mimicry in that it carves out and defines appropriate and inappropriate behavior of gendered bodies. The aunt killed herself because of the cultural weight the story had in her own life that eventually rendered her to the margins of society. The mother narrates the story to her daughter, sustaining the idea that a gendered body that acts inappropriately is a deadly body.

The daughter then narrates the story to the audience, but this time with a difference, a tactical response through mimicry intended to show the power of adapting and altering stories to make spaces for new possibilities. As the daughter narrates the story her mother told her, mimicry here is a tactic and the act of narration and storytelling becomes a moment of reappropriation and empowerment. The nameless daughter articulates her own ideas through her imagination as to why the aunt became pregnant, carving out new spaces of identity that cross boundaries of hegemonic appropriate behavior. The imaginative act of storytelling serves to shape her aunt's motivations and 
shows how identities are ambiguous, always in flux, existing within the realm of discourse and are often outside of boundaries of hegemony and control. Mimicry, as a tactic, also informs my research on performances of reappropriation and liminoid borderlands that move to spaces of freeing identity from powers of subjugation.

Given that mimicry cuts both ways, I want to critique the ways in which mimicry has been misused. As a performer, I strive to be a social agent, co-communicating with the Other, reconstructing our realities and experiences, drawing into question ethical implications. This positionality allows me, as Dwight Conquergood puts it, to "move between structures, to forge connections, to see together, to speak with instead of simply speaking about or for others" (Conquergood, 1995, p. 137). Conquergood reminds me through his essay, "Performing as a Moral Act: Ethnical Dimensions of the Ethnography of Performance," that I have an ethical responsibility to be critical of the ways in which I reconcile tensions surrounding representations of Chinese-American women for both the audience as well as the people I am performing. The ethical considerations that theoretically frame my performance are drawn from Conquergood's dialogical performance quadrants. The quadrants reflect four potential pitfalls that not only compromise the integrity of performance, but more importantly, dangerously harm and further marginalize the people for which the performer is performing.

The four ethical tensions are "the custodian's rip-off," "the enthusiast's infatuation," "the skeptic's cop-out" and "the curator's exhibitionism" (Conquergood, 1985). "The custodian's rip-off" is a problematic strategy of performance for it ignores the objections of a specific group to perform material appropriated from them. In this 
unethical situation, the performers perform the text because they believe that they will have an aesthetically strong performance. This approach sacrifices moral ethnographic guidelines for selfish performance motivations that violate and disregard cultural rights. "The enthusiast's infatuation" is detrimental because it attempts to underestimate the "Other" by making rash generalizations and strips people from claiming cultural connections. This stance ignores our differences and falsely assumes that everyone is alike as a strategy to insensitively and uncritically access and perform culture. "The skeptic's cop-out" uses similarity as a pre-requisite to perform specific groups and texts. An ethical ethnographic performance values performers who do not allow superficial markings to determine whether or not they can ethically and respectfully perform another's reality. Lastly, "the curator's exhibitionism" contrasts with the "enthusiast's infatuation" because this pitfall focuses on highlighting and exoticizing the "Other," which demoralizes and sensationalizes them (Conquergood, 1985). My performance aims to be critical by situating itself in the center of all four quadrants. The equilibrium state between the four ethical tensions is what Conquergood calls "dialogical performance" (Conquergood, 1985), in which different worldviews are foregrounded to foster a genuine conversation. "Dialogical performance" is based on a recognition of the tensions and struggles between self and "Other."

Conquergood's perspective informs my thesis performance in ways that question and tease out my own motivations and vision. I ask myself: in what ways am I reinforcing problematic cultural and gendered identities through my performance and in what ways am I engaging in a "dialogical performance?" My constant awareness of 
Conquergood's theoretical perspective heightens the stakes and forces me to question and consider the political and moral motivations that my scripting, directorial, and performance choices elicit. Though I am performing a literary work, as opposed to a text of non-fiction, such as oral histories, ethnographies, or personal narratives, the ethical imperatives inherent in my work are no less urgent. Because literature represents lives and people, "dialogic performance" is at work when the performers "must continuously play the oppositions between Identity and Difference" (Conquergood, 1985, p. 9). "Dialogical Performance" creates the ethical conditions for a genuine conversation between performer and performed that encourages speaking "with" rather "than" for (Conquergood, 1985).

This brings me to my last point: the efficacy of performance. Susan Haedicke (2002) explores the question of whether a particular performance can be said to be effective or not. While the rhetoric of "proof" and "effectiveness" work against the tenants of performance studies as idiosyncratic, pluralistic, and constantly in flux, Headicke, using Baz Kershaw's definition of performance efficacy, poetically offers a framework to think about efficacy in relationship to performance. She writes:

While the possible efficacy of a performance event is very difficult to measure...and attempting to establish a causal connection between theatre work and societal changes is not helpful...we should [instead] pay more attention to the conditions of performance that are most likely to produce an efficacious result... [that is to say] to evaluate efficacy more convincingly, we must consider the potential of performance (both in its specific sense as 'individual show' and in its general sense as a 'collection of practices') to achieve efficacy in a particular historical context. (Headicke, 2002, p. 112, italics mine) 
Because performance studies' paradigmatic language does not lend itself to equating "proof" with "effectiveness," reframing efficacy and performance into a question of potential is more meaningful. The potential for audience members and performers to "develop a critical awareness through dialogue of their social realities and recognize their ability to transform it through their own actions" (p.115) in relationship to the performances is a potential step towards critical awareness and action for social change. Likewise, in Theatre of The Oppressed, Boal (1979) argues that the efficacy and power of performance lies in its ability to prepare, train, and equip people with metaphorical tools for the revolution. The power of performance for Headicke, Kershaw, and Boal lies in its potential for revolutionary action, in its ability to move the passive audience towards social action. Throughout my performance and adaptation, I work to highlight my role as a performer that also questions my own actions in relationship to the material as well as the role of the audience in ways that encourage engaging with the performance in critical and self-reflexive ways. 


\section{CHAPTER THREE: METHODOLOGY: CRITICAL ADAPTATION OF}

\section{LITERATURE}

The methodology I used for my means of investigation is critical adaptation and performance of literature. Derek Goldman's (2006), "Ethnography and the Politics of Adaptation" provides in clear detail an explanation of the current conditions of critical adaptation of literature, which are particularly meaningful to my own thesis. Critical adaptation of literature is not the mimetic, linear representation of a preexisting text, as adaptations are often figured; rather it is "a transformational activity central to how performance operates as an embodied practice of making meaning and as a critical trope for...real life experiences" (Goldman, 2006, p. 367). Therefore, critical adaptation strives to create a space that centers and decenters the intersectionalities of oral engagement, textual fidelity, and reappropriation of text to make "deep connections between power, authorship, and text" (p.368). Dialogical performance, as a foundation of critical adaptation of literature, surfaces the importance of converging different perspectives into "a genuine conversation" (Conquergood, 1985), while maintaining an artistic representation. Therefore, a critical adaptation becomes a conversation between multiple voices through and within one text. As Goldman (2006) puts it, critical adaptations of literature attempt to create new spaces:

In which knowledge and power come together not merely to reaffirm difference but to interrogate it, to open up broader theoretical considerations, to tease out limitations and engage in a vision of community in which different voices define themselves in terms of their distinct social formations and broader collective hopes. (Goldman, 2006, p. 375) 
The goal of converging multiple voices, ideas, and perspectives is not simply to sustain moments of difference or similarity; rather it is to explore the points of strife as well as the motivations and connections between them. Critical adaptation has the potential to be a tactic for "dismantling and reinventing power structures" (p. 377) for transformation and new ways of articulating existence. By using critical adaptation as a tactical response, we can assert new narratives that challenge marginalizing canonical texts. These adaptations then build upon one another to engage in a dialogue between perspectives that center on trying to make meaning, rather than simply surveying for it. Adaptation, as retelling and re-storying, might function as a source of agency and transgression. As Linda Hutcheon states, "Adaptation is repetition, but repetition without replication" (Hutcheon, 2006, p.7). It is a process of creation through reinterpretation. Adaptation as repetition as mimicry, in Bhabha's sense, holds a mirror up to the discursive structures of power, revealing and highlighting the strategic mechanisms that marginalize; hence, it becomes a tactical tool that alters and reappropriates actions and texts that move beyond the structures of uncritical replication. In Hutcheon's words, "the advantage of the more general anthropological usage in thinking about adaptation is that it implies agency: people pick and choose what they want to transplant to their own soil" (Hutcheon, 2006, p. 150). Adaptation is, thus, agency on an intrinsic level, in that social structures of power can be identified and dismantled at least symbolically within the adapted text. Adaptation itself becomes a "liminoid" space, to use Victor Turner's term, in which new possibilities of rearticulating the past in unforeseen ways might be not only greatly empowering as a product, but transcendent as a process as well. The ability to 
emphasize, hide, challenge, and adapt something else to elicit alternative responses from hegemonic discourses is an invaluable tool. It allows us to interrogate a question, theme, and idea with mimetic reperformance, in Bhabha's sense of mimetic as tactical transformation. Critical adaptation of literature also allows for marginalized voices to be heard alongside and within a text.

Hutcheon's theories inform my script by emphasizing the framework and processes of critical adaptation. Adaptation as "a process [of] (creative reinterpretation and palimpsestic intertextuality)" (Hutcheon, 2006, p. 22) draws attention to the ways in which that process can be engaged and altered. For my thesis, the processes include considering what I wanted to adapt, my mode of engagement, what themes I wanted to explore, and how I would outline my adaptation. When I re-read Hong Kingston's novel, I knew that I wanted to translate it into a live performance. After taking an adaptation and scriptwriting seminar at San José State, I became equipped with the foundational tools to write an adaptation. Hutcheon's theoretical guidelines of adaptation clarified the processes of remediating a particular narrative in order to engage in intertextuality with multiple voices.

In the spring semester of 2009, I took a scriptwriting class with the Theatre Arts Department at San José State University. In this seminar, I learned what shape I wanted the script to take and I wrote the preliminary draft. First, I outlined the entire novel by chapters, noting what each chapter explored thematically and what quotes stood out. I then started to write my script based on what themes I wanted to explore and what sections I wanted to include from the book. After several readings of my script by 
myself, the professor (Dr. Matthew Spangler), and other students in the class, I rewrote it and after six revisions, I had a completed version of my script. In the fall semester of 2009, during the months of October and November, I rehearsed my performance and made more revisions based on what worked and what did not in a live setting. For example, I changed lines for coherency, added music cues, and adjusted my blocking choices. In doing so, I attempted to create a new space of transformation and re-storying.

For me, The Woman Warrior lends itself to a work of adaptation and a live performance because of the ways in which literature functions to articulate social constructions of identity and how performance might draw attention to reenvisioning those social roles. There were many moments where I related to and questioned the book, which solicited an internal dialogue between Hong Kingston and me. I began to author and create alternative and supporting ideas. Because literature and storytelling communicate and sustain particular ideologies, an adaptation of literature draws attention to the possibility of rewriting and reinterpreting social constructed ideologies.

After settling on a performance adaptation, I began the process of writing my script. I first outlined the entire book, dividing themes from my favorite quotations in each of the five chapters. I specifically highlighted the quotes I was drawn to in each of the chapters because I knew I could use them in some capacity in the script, as either a point of agreement or divergence. Of the selected quotations, the patterns and themes that emerged for me touched directly on issues of gender, culture, and transglobal migration and the hegemonic social scripts associated with them. Four of the following 
scenes are adapted from the novel; two are my own writing. The scenes in my script include the following:

Scene I: no name woman

\section{Scene II: MAD SWORDSWOMAN}

Scene III: china doll, useless girl

Scene IV: Warrior Lessons Magazine Rehab

Scene V: You Better Talk

\section{Scene VI: Tightly Unbound}

Scenes one, two, three, and five are chapters from the novel, while scenes four and six are primarily my own writing. Within all six scenes, I interwove my writing with that of Hong Kingston's words to edit and transition between passages for clarity, but I also did this as an artistic opportunity to rearticulate and engage with the text from my own critical paradigmatic perspective. Specifically, the dialogical conversation between Hong Kingston and my voice is an opportunity for me to respond back to Hong Kingston in places where I wanted to explore the issues of gender, culture, and transglobal migration differently. For example, I added Scene IV: Warrior Lessons Magazine Rehab because I wanted to interrogate and make visible the ways in which gender is circumscribed on the body within the hegemonic discourses of "white beauty." In the novel, Hong Kingston writes a great deal about the ways in which gender constructions in China are problematic and filled with tension, however, I wanted to pair that conversation with another layer of the ways in which gender constructions are also negotiated in the United States. In that scene, in particular, I use as a moment where I speak back to Kingston's novel. While 
the entire book explores issues of gender and race, the two chapters that I intertwined with my own writing spoke directly to my goals and ideas articulating the struggles of marginality of identities and the difficulty of negotiating spaces for alternative performativity.

Another important theme that I wanted to stress even more than Hong Kingston does in her novel is her use of magic realism in relationship to the memoir narratives. By blurring the lines of my own writing to include scenes of magic realism, my script does not follow a linear form of storytelling. This nonlinear approach speaks directly to my use of Anzaldúa, Butler, and Turner's notions of ambiguity and liminality, themes that my script structurally incorporates.

My performance ran forty-five minutes. Therefore, in order to make visible the themes of transcultural and gendered identity, I kept only three of the five chapters in the novel. Even within the chapters, I struggled with editing the text. After all, I could not realistically keep all of the novel's language in the script, so I mediated and negotiated that struggle by turning to passages that I found meaningful, but needed to cut for the sake of time, into physical performative moments. It was at those moments where I found editing the script a challenge. However, those challenges reflected my methodology of critical adaptation because it was at those hinges and points of difficulty where I could interrogate those sites of power. For example, at the end of scene two I communicate a move from China to America through a physical and musical sequence. I drag a black sheet, covered with dirt, a broken egg, a dead flower, and red tulle, all 
symbolic representations of Chinese gendered identity, around the stage in an exhausted manner to communicate a long journey from one place to another.

In addition to the complexities and ethical principles of adaptation, the issue of authorship and even the word "author" itself becomes an interesting tension that I explore. Both Barthes's (1977) and Foucault's (1987) theories of authors and authorship question and examine authorial intentions and power. As Barthes states, “...we know that to give writing its future, it is necessary to overthrow the myth: the birth of the reader must be at the cost of the death of an Author" (Barthes, 1977, p. 148). Although the cultural capital of the author remains powerful (Foucault, 1987), readers, with their multiple and varied interpretations of the text at hand, are what makes the story, song, dance, play, or performance powerful and meaningful. As Barthes points out, we can no longer confine the power of the text to the author and her/his experiences, histories, ideas, and ownership; rather it exists in the minds and hearts of audiences. Therefore, while I may intend to explore transcultural and gendered performances within a particular frame, the possibility of multiple and varied interpretations of my adaptation enriches and develops its themes even further.

I turn to D. Soyini Madison's (2005) theory of “critical ethnography” to inform my performance of literature as a critical adaptation. As she puts it, the critical examination:

Begins with an ethical responsibility to address processes of unfairness or injustice within a particular lived domain...the critical ethnographer also takes us beneath surface appearances, disrupts the status quo, and unsettles both neutrality and taken-for-granted assumptions by bringing to light underlying and obscure operations of power and control. (Madison, 2005, p. 5) 
Like Hutcheon's (2006) theory of adaptation as a mode of investigation that solicits opportunities to question, alter, and reinterpret as agency, Madison also argues that there are ethical and political responsibilities when exposing and dismantling structures of power. Madison's call for the critical scholar to "disrupt the status quo and unsettle...the taken-for-granted assumptions" (2005, p.5) is something I deliberately sought to do in this performance adaptation.

In piecing together and adapting my methodology for my thesis, I now move from Madison's application of the critical theory to Robert Breen's chamber theatre. My critical adaptation of literature has its roots in Breen's chamber theatre, which Breen defines as:

the technique for presenting narrative fiction on the stage in such a way as to take full advantage of all the theatrical devices of the stage without sacrificing the narrative elements of the literature...that explores the relationships among characters in a narrative context provided by the narrators intimate association with the audience. (Breen, 1978, p. 4)

Chamber theatre informs my work in its aesthetic choices, such as centering on the virtue of storytelling, representing the illusion of reality, and the use of symbolic props. Chamber theatre allows for focus on the text with minimal, yet symbolic theatricality through the usage of communicatively symbolic props, music, lighting, costuming, and blocking. Symbolic representations draw attention to the use of the symbols themselves and the ability to change those symbols through specific acts of meaning making (Breen, 1978). The breaking of the fourth wall and speaking directly to the audience, often taboo in traditional theatre, invoke a symbiotic relationship between the audience and the performer. Through a performance of Hong Kingston's novel, I use critical adaptation of 
literature with elements of chamber theatre as a lens through which to represent and share a complex narrative of a particular Chinese-American woman as well as to call into question the political structures that produce marginality for the purpose of moving beyond them.

At the onset of my adaptation, I considered carefully how I wanted to approach this project. In keeping with the story I wanted to share, I considered what sections I needed to preserve, alter, and edit out. While some of the theoretical and aesthetic choices in my adaptation mirror those of Robert Breen's chamber theatre, my adaptation pushes back and resists some of Breen's constructs, particularly with regard to the process of scripting. Breen argues that the adapter, in any circumstance, should not cut or alter any language from the original source. In doing so, Breen argues, the adapter respects the original author's intentions and story. However, I consciously alter, rewrite, and include much of my own writing within my adaptation as a means of revealing the power of authorship and identity construction. If readers draw inspiration and knowledge from literature about their cultural identity, then the ability to rewrite and challenge literature opens up spaces for empowerment and authorship.

Though my adaptation is not a verbatim replication of Hong Kingston's novel, I respect it in ways that allow me to challenge, extend, and envision a more nuanced and personal process of identity construction. Both Hong Kingston's novel and my adaptation of it are in conversation with one another, trying to make the process of identity construction challenging and meaningful. My adaptation does not lack authorial fidelity, rather it encourages textual plurality. As Hutcheon argues, "fidelity is based on 
the implied assumption that adapters aim simply to reproduce the adapted text" (Hutcheon, 2006, p.7). My thesis script aims to do much more than simply reproduce; it aims to transform and reinterpret collective narratives. For Hutcheon, "adaptations...can be seen as mixed in intent: contested homage" (p.7). In other words, they might both respect as well as challenge the original source material. Critical adaptations of literature function to move beyond the superficial arguments of originality and fidelity to be transformative recreation.

Storytelling and literature function as sources of cultural identity. Said says that, "nations themselves are narrations. The power to narrate, or to block other narratives from forming and emerging, is very important to culture and imperialism, and constitutes one of the main connections between them" (Said, 1993, p. xiii). Therefore, an adaptation of literature might function as an opportunity to narrate an alternative point of view, creating a new and renewed sense of cultural identity. To narrate an adaptation of Hong Kingston's novel allows me to forward, challenge, transform, and exchange my specific critical paradigmatic perspective of identity construction with audience members as a dialogic performance moment. Narrating culture is not a solitary tranquil act, instead, in the words of Said, it:

causes [us] to engage [with] one another. Far from being a placid realm of Apollonian gentility, culture can even be a battleground on which causes expose themselves to the light of day and contend with one another, making it apparent that, for instance, American, French, or Indian students who are taught to read their national classics before they read others are expected to appreciate and belong loyally, often uncritically, to their nations and traditions while denigrating or fighting against others. (Said, 1993, p. xiii) 
In my script, both Hong Kingston's and my own authorial voice function together as a critical engagement and exchange of cultural ideologies that aim to push for an ambiguous performance, one that constantly questions notions of identity construction. My performance adaptation seeks to become a site in which a multitude of voices are heard side by side, sometimes in opposition and sometimes in solidarity, but always in critical self-reflexive ways.

In drawing upon and making connections between Goldman's theory on the possibility of critical adaptation of literature, Madison's theory on critical ethnography, and Breen's chamber theatre techniques, my critical adaptation of The Woman Warrior has the potential and capacity to disrupt and interrogate the relationships between knowledge, power, and the construction of gender and cultural identity in hopes of contributing to the fields of adaptation, critical studies, and performance studies. In addition, adding Hutcheon's and Bhabha's notions on adaptation as repetition and mimicry to my methodology opens up the possibility, for me as a performer, to participate in the social world and to engage and respond, in tactical ways to hegemonies of oppression. In this sense, my performance of The Woman Warrior has the capacity to function as a moment of agency, in which I embody critical adaptation as a means of transgression and disruption, to try out various tactics of empowerment. 


\section{CHAPTER FOUR: DISCUSSION}

In this section, I will explore and tease out the ways in which my scripting and directorial choices for this thesis performance aim to make visible the hegemonic discourses associated with the constructs of gender, culture, and transglobal migration from China to the United States. In addition, I explore how those discourses might be resisted, internalized, reappropriated, and queered through a live performance. I want to ask: in what ways do my scripting choices tactically call into question the often binding social constructions of identity? In asking this question, I hope to challenge binary and rigidly fixed constructions of identity and open up spaces for more ambiguous ones. I will also explore my directorial choices of this thesis performance, through my use of blocking, props, lights, and music, as they also aim to move between and within structures of marginality and empowerment.

On the evenings of November $5^{\text {th }}, 6^{\text {th }}$, and $7^{\text {th }} 2009$, I premiered my one woman thesis performance for an audience of approximately one hundred and twenty people at San José State University’s Black Box Theatre in Hugh Gillis Hall room 231. The performance lasted nearly forty-five minutes with a fifteen minute question and answer session at the end. The performance was divided into six scenes. In each of the scenes, I explore the social and cultural landscapes of a gendered and transcultural identity played out in both Hong Kingston's novel as well as in my own life. Throughout each of the scenes, I performed embodied acts that reference something larger than themselves. This extra textual referencing is what gives the specific acts meaning. My performance aims to speak back to the referential with a specific social and cultural motivation as a means 
of reappropriating the reference. In my performance, the social actions are never absent of a critical motivation to either rewrite, reaffirm, or rethink the structures of performativity. The social actions in each of the six scenes not only represent a specific embodied act in that moment in time, but they also represent agency for the performer and audience, particularly the ways in which that agency is tactical or strategic, empowering or infringing, or a complicated mediation between all four.

In all six scenes, I struggle with performing identity, an identity that negotiates the homespaces of strategic disempowerment and tactical assertion. The performances in each of the scenes teeter back and forth on a seesaw, making the spaces of empowerment and disempowerment ambiguous. In that struggle between performing identity, I have embodied moments where I felt empowered and where I felt marginalized, unsure of where those distinctions were drawn. Embracing the ambiguity of identity is, for me, a tactic, a means of living within those tensions as well as a way of resisting hegemonic structures of control.

Keeping the empowering potential of adaptation in mind, my choice to adapt a memoir adds another layer to the significance of this specific thesis project. As Moreman states the:

memoir, a specific literary genre...written about by Communication scholars [is] a pedagogical tool (see Hampton; Jensen) and as [an] opportunity to gain insight into private lives... [they are also complex when trying to] locate truth(s) [because] memories are how one remembers one's own life, while an autobiography is history. (Moreman, 2009, p. 347)

Memoirs can be empowering as they are adaptations of one's own life, freeing exercises to remember, recall, and privilege specific accounts over others. My adaptation of a 
memoir blurs the line between what is considered "truth" in relationship to constructing a Chinese American woman's identity, aiming to destabilize its structural power, and instead reinforcing a specific, personal approach in the performance of identity construction. Therefore, my script, which itself is an adaptation of an adaptation, becomes a performative mode of identity construction; as Moreman says, "a process of creating the self through text, allowing a persona to exist that is interpreted over and over by other readers...[letting] these interpretations [become] possible empowerments for the reading audiences" (p. 349). My performance script explores the hegemonic discourses associated with the constructs of gender, culture, and transglobal migration from China to the United States and how these discourses might be made visible, resisted, internalized, reappropriated, and queered through live performance using the methodology of critical adaptation.

I hope my adaptation has the potential to empower not only myself, but also audiences to explore and interpret their own meanings and notions of identity. I invite audience members to view my adaptation as a tactical exercise to make meaning together. Like a memoir, my critical adaptation is a "creation of [a] discursive space [where] the margins are transformed into the center of a new society, and the disempowered are empowered" (Flores, 1996, p. 152). My critical adaptation of Hong Kingston's novel is a creation of a new representation of constructed identity and the ways in which that identity is performed and re-performed. Throughout my script, I seek to emphasize and make visible the complicated negotiations and tensions of a single account of growing up as a Chinese American Woman. In addition to the discursive elements in my script, I 
also consider the ways in which my directorial choices can explore how hegemonic discourses associated with the constructs of gender, culture, and transglobal migration might be made visible, resisted, internalized, reappropriated, and queered. I seek to understand how live performance itself illuminates these discourses and the ways in which my directorial choices disrupt and/or reaffirm them. I also employ a variety of staging principles, such as blocking, music, and props to unify the theoretical motivations and concerns with the aesthetic artistic spectacle.

\section{Blocking}

According to Judy Yordon (1997), the performer's blocking choices represent and communicate different concerns and purposes. For this performance, I use a proscenium stage that is divided into nine areas, which include upstage right, upstage center, upstage left, center stage right, center stage, center stage left, downstage right, downstage center, and downstage left. As Yordan argues, upstage right, upstage center, and upstage left are traditionally considered places of the least amount of power and stage presence, because those positions on stage are more difficult for audience members to see. As a director, I can then use these blocking choices to underscore the ways in which the marginalized are often hidden and difficult to see in society.

For my performance, I used the nine traditional stage directions to block movement to explore moments of power, marginality, confinement, and reappropriation. In Scene I: no name woman, I enter the stage by walking out from behind the audience, passing through them and positioning myself downcenter stage. My choice to enter from 
behind the audience suggests two ideas. First, I want to frame the character of the young Chinese girl as a part of society with the audience representing the body of the social world and this narrative as part of that world. I do not start the performance already in position on stage because I want to express that the narrative of the Chinese girl did not just appear out of thin air; but rather her story is a part of the social world in which we all live. Second, I walk from behind the audience rather than from within the audience as a means to illustrate the ways in which this particular narrative comes from is the margins of hegemonic American discourses. While her story is a part of the social world, it exists on the peripheries.

Much of my performance is blocked in a semi arc that starts center stage right and moves downstage right, to down center stage, to downstage left and back up to center stage left. In the middle of the arc, center stage, is a bench covered in red fabric. Throughout the performance, I stay in between the red bench and the audience, usually downstage center, with the exception of when I move beyond and around the arc. For a few moments, when I am positioned downstage center, I am articulating a lack of movement, a moment of bound identity. Moments where I move beyond and within the arc are moments where I challenge my positionality of bound identity as a means of empowerment. This is most present in Scene I: no name woman, as the daughter narrates the story that her mother told her about her dead aunt. For example, in Scene I, when the young girl begins to describe that her aunt was raped, I stay down stage center, framing an identity that is controlled, docile, and abeyant. In this moment the daughter regards the story her mother told her as a warning of female identity. 
However, when the daughter "contests the rhetoric of narrative knowing" (Pollock, 2008, p. 122), she begins to retell and re-story an alternative narrative. This narrative frames the aunt as a powerful woman who chooses to step outside the boundaries of gender constraints. When the daughter provides this alternative reason as to why her aunt became pregnant, I move beyond the arc, articulating a choice, a sense of agency and power. In Scene II: MAD SWORDSWOMAN as a Chinese warrior woman, I freely move around the stage as a Chinese warrior woman exploring power and agency. However, in Scene III: china doll, useless girl, I suddenly sit down on the bench, which is positioned center stage, to stop my movement, to lock my body into a position of disempowerment and marginality. Between those two scenes, the character moves from China to America. My constant moving around the space in Scene II and the sudden stagnancy in Scene III underscores the ways in which non-conforming ambiguous identities are not only unaccepted in the hegemonic American discourses, but are pushed to the margins. While I am still positioned center stage, a place of power, I am sitting down, immobile and vacuous. The juxtaposition between the positionality of power and the immobile actions of the character, challenges what is thought of as empowering. Although I am in a position of power and acknowledgment, my sitting down references the lack of tools to fit within the structures of power.

I explore another juxtaposition and even ironic twist on the positionality of power demonstrated in Scene III: Warrior Lessons Magazine Rehab and Scene VI: Tightly Unbound. In both scenes, I am standing on top of the red bench, center stage. In Scene III, I am standing on the bench, not in a position of empowerment; rather, the red bench is 
symbolic of the ways in which the gendered body of womanliness is placed within a frame of voyeurism and put on a pedestal within the hegemonic structures of gender construction. I am standing on the bench not as an image of freedom and power, but on the contrary, as a position of being gazed upon and exoticized. However, in Scene VI: Tightly Unbound, I stand on the red bench as a means of reappropriation and empowerment, as I use the height as a symbolic gesture of being heard and in control of the gaze. I am standing on the bench, reappropriating the pedestal to fit within my construction of power.

\section{Music}

While some of my music choices throughout the performance function to enhance the dramatic effect of a particular scene or offer transitions between scenes, the music choices also work to communicate alongside the text of the script in critical and sometimes ironic ways. In Scene I, as I am walking from behind the audience to down stage center, music plays as I make my entrance. The music is by the Chinese artist Pui Yin Yeung, a track titled “I hope your heart remembers me" (願君心記取 ), from the album Ancient Green (綠古筝). The music is entirely instrumental and not quite discernable in terms of locale. As the music plays, audience members begin to pick up on Eastern influences in the instruments, but it is still questionable as to where exactly the music is from. I specifically chose this type of instrumental music as a way of providing a performative reiteration for the ways in which Western audiences exoticize "Orient" Asian bodies and culture. In fact, this ambiguous music track speaks against the themes 
of the performance, as the music problematically cuts across a myriad of countries and cultures, lumping my body in the performance as "Oriental." Playing off Edward Said's (1979) notion of "Orientalism," this particular music choice signals the Western imagination that creates an exotic mythical narrative about Asian bodies, specifically a Chinese body in my performance. According to Said, the "Oriental" myth was created by and for Western audiences to inflict colonial oppression on the racialized "Othered" body. The textual undertones of the music provide a sense of irony, as the music, my body, and the script come together in radical tension. Here, the music functions to frame the performance of my body as "Oriental," a racial other, to the west. The Chinese music that is ambiguous and unfamiliar to Western audiences, inscribes a mythical, exotic performance to my body, making the audience's assumptions about my racial construction apparent, in the hope of challenging it.

Another choice of music that offers an ironic critical voice that is in tension with the text is in Scene III: china doll, useless girl. In this scene, the character moves to America, and I play Neil Diamond's “They're Coming to America," a popular American song about immigration to America. The lyrics and cheerful rhythm of the song speak to immigration to America as a welcoming, utopian experience. However, as I play the song, the lights are dimmed, and I move around the space carrying around a pile of dirt in a sack, symbolic of cultural baggage. Together the lyrics of the song, the communicative acts of my performing body, and my underlying authorial voice, critique the irony of hegemonic discourses of transglobal migration as welcoming. I play this specific music track, not to celebrate immigration to the United States as a rapturous experience, but as a 
painful and difficult one. In this scene, the music juxtaposed with the discursive performance acts and the text exposes the complicated negotiations of finding a homespace within this story of immigration.

\section{Props}

Along with the use of text, blocking, and music as dramatic devices to reveal and surface the thematic motivations of this particular story, I also used props to explore the text in visceral and symbolic ways. I used props throughout my performance for their symbolic connotations, allowing room for the use of metaphors and multiple readings of one particular scene by the audience. Metaphors, conveyed through the use of symbolic props, encourage the audience to use its imagination and question what is possible in relation to identity construction. In doing so, I want the audience to engage identity construction with the notion that constructing one's identity is highly subjective, varied, and multiple, just as are metaphors and symbolic props. Rather than using literal translations of the scenes at hand, I use symbolism through props to open up spaces for imagination, adaptation, and dialogue.

My use of props throughout the performance entailed a suggestive and imaginary approach. Judy Yordon argues that "suggestion means trying to avoid falling into the trap of making everything literal or representational... and economy means finding the simplest way to stage elements so that the production features the language and the images rather than the special effects" (Yordon, 1997, p. 82). Therefore, not only does suggestion and economy of symbolism communicate much more to audiences than the 
literal, but they also underscore the idea that relying on literal translations narrows interpretation to a singular interpretation of the performance. Specifically, in relationship to the main character's struggle in finding home-spaces of identity, a literal representation of the text would work against the tenant of the script in privileging a singular perspective and approach to that journey of identity construction. I use a variety of props that I manipulate in different ways to make the hegemonic discourses associated with the constructs of gender, culture, and transglobal migration visible, resisted, internalized, reappropriated, and queered. I use the props throughout the performance in tactical and strategic ways to unmask the power structures of marginality. I will discuss each of the props and the ways in which their symbolic use seeks to invoke and materialize the themes that they represent.

\section{Scene I: no name woman}

I begin the performance with Scene I: no name woman, a story of a young Chinese girl imagining what could have happened to her dead aunt, who drowned herself and her newborn baby down the family well. Throughout the scene, I make the gender and social scripts of a woman's identity in China visible through the use of text and props. As the scene progresses, the main character, the young Chinese girl, resists and reappropriates the gendered social scripts through a subversive act of storytelling. The scene begins with a moment of storytelling, the young girl's mother explaining why her pregnant aunt committed suicide. Her aunt became pregnant by a man other than her husband. My choice to make the moment of storytelling the very first thing the audience 
hears is to make the audience aware of the performance as a story. This is not only a story for the audience, but it is also a moment of mother to daughter instruction. As the mother says:

You must not tell anyone what I am about to tell you. In China your father had a pregnant sister who killed herself. She jumped into the family well... Now that you have started to menstruate, what happened to her could happen to you. Don't humiliate us. (See Appendix A, p.1)

The story is meant to inform the young girl as to what actions, ideas, and performances are socially permitted and which are condemned. The story functions as an act of control, circumscribing gender constructions on her body. The young girl is taught the oppressive hegemonic discourses of gender roles in China through the process of storytelling. The stories reveal the roles of women to be limited to functionality and precision, confining and disciplining the body.

But as the daughter embodies and repeats her mother's story of her dead aunt in the beginning of the scene, she gives power and meaning to the rhetoric of disempowered female identity.

My mother had told me once and for all the useful parts about who I should be in the world through the telling of my aunt's story. She will add nothing unless powered by Necessity, a riverbank that guides her life. Women must be precise and only speak the necessities, nothing more. She planted vegetable gardens rather than lawns; carried odd-shaped tomatoes home from the fields and ate food left for the gods. Because to be a woman, to have a daughter in starvation time, was a waste enough. But the story my mother told me about my aunt wasn't enough for me. (See Appendix A, p.2)

The daughter needed more of the story, an alternative to the binding and subjugating narrative told by her mother. The daughter tests and reconfigures the mother's story in 
her own personal and subjective account as a means of altering and contesting narrative power. As Conquergood argues:

Knowledge is not stories in storytelling so much as it is enacted, reconfigured, tested, and engaged by imaginative summonings and interpretive replays of past events in the light of present situations and struggles. Active and emergent instead of abstract and inert, narrative knowing recalls and recasts experience into meaningful signposts and supports for ongoing action. (Conquergood, 1993, p.337)

The young girl disrupts her mother's story with her own ideas as to what might have happened to her aunt, pushing back on her mother's grand narrative, resisting what appeared as "truth" and challenging what womanliness means to her. The young girl resists the oppressive categorization that women function to only exist for heteronormative sexuality. She begins to reappropriate the act of storytelling to insert her own ideas as to why her aunt became pregnant. The young girl reappropriates the grand narrative, opening up spaces for alternative non-conventional narratives through her own act of storytelling. As Said argues, "conventional narrative is...central to imperialism's appropriative and dominative attributes...narrative itself is a representation of power" (Said, 1993, p. 273), and non-hegemonic narratives, like the one the young girl offers, challenge this representation of power and its pervasive hold on the construction of identity. The young girl authored alternative and subversive narratives of identity as an act of power and agency. She argued that the aunt chose to honor herself first and chose this lifestyle as an act of subversion, outside the limits of control. But because the aunt's actions were not sanctioned by hegemonic discourses of female behavior and identity, the aunt was marginalized and ultimately paid for this with her life. 
I end Scene I: no name woman by concluding the original story the mother told in the beginning as a way to represent the current discourse and realities of controlled gendered bodies and the ways in which attempting to resist and reappropriate those hegemonic discourses can be difficult because of our strong historical ties to social scripts and grand narratives. In the performance, I end with performing the aunt in labor and then going to the family well to drown her child. At that moment, I introduce a potted plant to further articulate the fate of the unwanted child. In this sense, the baby girl is no different than a pile of dirt. The narrator indicates this when she says:

And when she went down to touch the hot, wet, moving mass beneath her, surely smaller than anything human, she realized that it was human after all, fingers, toes, nails, and nose...the child laid there butt in the air, feet precisely tucked one under the other. She realized at its birth, she had taken the child with her into the wastes. It was probably a girl, there is always hope of forgiveness for boys. (See Appendix A, p.6-7)

Here, the aunt knew that her baby girl was doomed from the onset of her life. The aunt realized that the baby, who lay precisely in her arms, would never move beyond the hegemonic structures of marginality. The discourses that already defined her child pushed her baby and herself to the margins of society. I introduce the dirtrepresentative of the baby girl, the aunt, and the narrator herself - in this scene to contextualize pain, suffering, and violence in relationship to the constructions of gender within hegemonic Chinese discourses. After the aunt gives birth, she picks up the child and realizes that she gave birth to a baby girl. Foreseeing no opportunity for hope, the aunt slowly walks to the well and dumps the child and herself into the well. The dirt, poured out on the ground, destroying the delicate, beautiful orchid, becomes a symbol for 
the cultural caché of women in a patriarchal society, in which women are not only devalued, but deserve to be metaphorically dumped out.

Lastly, at the end of Scene I, after I pour out the potted orchid and sit down, I look up at seventy-six white, pink, and light green orchids hung from the ceiling with red string. The hanging orchids sway slightly from left to right as the air blows on them, making them seem alive and present. At that moment of sorrow for the drowned aunt and baby girl, I look up at the myriad of other orchids, referencing the oppression of women as nuanced, varied, and multiple. While this story offers a specific, particular narrative of oppression, the other orchids become symbolic of other marginalized voices that are unheard.

My choice to end with the mother's version of the story functions as a representation of the difficulties in challenging conventional narratives as an intentional act of empowerment. Although the possibility for agency and empowerment exists by challenging conventional stories of identity and creating subaltern ones, our strong ties to conventional grand narratives make that realization of empowerment difficult to realize. The competing voices in the scene, that of the mother and that of the daughter telling the mother's story, results in the mother's voice taking precedence and trumping the possibility for change and empowerment. Ending with the mother's version of the story, in this sense, mirrors the ways in which challenging the status quo, or grand narratives, does not always result in making room for nonconforming and ambiguous identities. The final gesture in the scene with the mother's story marks identity as stagnant and singular rather than open, transitory, nonconforming, and ambiguous, much like the ways in 
which the hegemonic power structures confine bodies. Therefore, while the adaptation and reiteration of a memoir can function as an empowering form of expression it can also be reaffirming of hegemonic structures.

Additionally, I use red sheer tulle, approximately twenty-five feet in length, to explore the ways in which the hegemonic discourses of identity construction are made visible. Throughout the performance, I interweave and reuse the red tulle and a variety of other props in each scene. While the use of red within Chinese culture is symbolic of good luck, it also speaks to lust, pain, love, and violence within a Western perspective. These contradictory symbols speak together to communicate both the painful and beautiful experiences wrapped within this narrative of a Chinese American immigrant girl. As most all of my props carry dueling tensions between pain and pleasure, the red tulle functions to be exemplary of these tensions. For moments in the performance, the red tulle is a source of pain, lost, and bound identity, whereas in others, the red tulle is symbolic of power, control, and reappropriation. In Scene I: no name woman, I tied the red tulle to a collar around my neck like a leash, holding out one end of the tulle. As the scene progresses, the audience hears the story of the aunt who was found pregnant and dead in the well. The mother is telling the story to her daughter, the young Chinese girl, as a warning and lesson of her gendered identity. The use of the red tulle as a leash in that particular moment in the scene is emblematic of the conventional linear progression of domesticity on gendered bodies. In China, the red line the tulle forms, mirrors the violent line in which women are confined as a means to perform obedience, sexuality, sex, and motherhood, and if any of these roles are broken or unfulfilled, then her life will 
result in death. I perform the rape scene as I spread open my legs and let the red tulle drop in between them and I subsequently perform pregnancy as I bundle the red tulle and hold it up to my belly. I used these props to speak to the subjection of gendered identities that I sought to explore through this performance.

\section{Scene II: MAD SWORDSWOMAN \& Scene III: china doll, useless girl}

In Scenes II and III, the hegemonic discourses associated with the constructs of gender, culture, and transglobal migration are not only made visible in relationship to the scripting and directorial choices, but they are also resisted, reappropriated, queered, and internalized. With Scenes II and III back to back, my use of scripting and language choices makes visible and reveals the conflicting cultural ideologies of what was once a tactic of power in China and later becomes a hindrance in America.

Scene II: MAD SWORDSWOMAN, begins with the young girl embarking on a journey to learn the ways of a warrior taught by an old woman who turns into a crane. I begin the scene with my legs spread over the spilled dirt, making visible the ways in which my body and the character refuses to be framed within the hegemonic discourses of "woman" as worthless and bound. The scene begins with the story of how powerful Chinese woman are and the lengths society took in order to control their power through feet binding. The story of feet binding and my performance of my feet outside the dirt resist and reappropriate the hegemonic gender constructions, creating a discursive space for transgression and empowerment. This overt action of not touching the dirt and spreading my legs over it is illustrative of my choice of resisting the category of garbage, 
devalued identity. As I move freely around the stage, I am not a delicate orchid confined to a pot and then pushed down to the grounds of society.

Then the girl narrates the story of a woman warrior who was trained by a crane the ways of fighting and protection. The story of the crane and the warrior lessons are framed as a dream in the performance, which materialize on stage, blurring the line between reality and fiction. I script the warrior lessons as a dream to frame this particular narrative in the memoir as a moment of playfulness, ambiguity, and possibility. My scripting of the text blurs the lines between fiction and nonfiction, as a means of challenging what is deemed unreal, unnatural, and untrue to reveal the rigid structures and binaries of control and to open up spaces for ambiguous "truth" as empowering. And when the young girl became the warrior in her dreams, her mother told her that she must:

Kneel here...we are going to carve revenge on your back... and as she carved, the crimson blood dripped down her back and soaked the white pillow beneath her...she got up put on men's clothing and armor and tied her hair in a man's fashion. And for two years her squad didn't know who she was, she had become an expert trickster, to protect her identity and to give her power. (See Appendix A, p.13)

This moment in the performance and text articulates the ways in which the girl's body was violently marked in order to engage with structures of power. This particular passage in the script, amalgamating gender constructs, magic realism, storytelling, and marking the body, draws attention to the tactical possibilities and strategic limits of identity construction. In the words of Judith Butler:

The locus of intractability, whether in "sex" or "gender" or in the very meaning of "construction," provides a clue to what cultural possibilities can and cannot become mobilized through any further analysis. The limits of the discursive analysis of gender presuppose and preempt the possibilities of imaginable and realizable gender configurations within 
culture. This is not to say that any and all gendered possibilities are open, but that the boundaries of analysis suggest the limits of a discursively conditioned experience. The limits are always set within the terms of a hegemonic cultural discourse predicated on binary structures that appear as the language of universal rationality. (Butler, 1990, p. 14)

The performance has the potential to make visible the ways in which the hegemonic discourses in relationship to gender construction bind and mark the narrator's body as well as the ways in which she attempts to challenge and transgress the discursive limitations. In the performance, I let the red tulle drip down my back, performing the moment of marking on the body. The text and the performance reveal and make visible the Chinese girl's tactical response to marginality, as she became a trickster, challenging the conventional structures of power, masculinity, and dominance. However, the young girl also internalizes and participates in the structures of gender construction because she dichotomizes and links masculinity and power with male and femininity and weakness with female, conflating and assigning gender roles to human bodies. Later, I use the red tulle as a sword giving me the strength to protect myself, a source of power. I control the red tulle as a sword, as opposed to the previous scene in which the red tulle was a leash that controlled me. Here, the red tulle functions both as a moment of magic realism as well as an act of mimicry. In several scenes, I used the red tulle to control and bind my body and in another it is used as a means of power and protection. The red tulle operates as both a source of oppression and empowerment, like the ways in which mimicry can function as both tactical and strategic responses. This moment of magic realism co-exists with a tension of possibility and distance. The young girl's dream to become a woman 
warrior is realizable, but distant as the dream quickly ends when her move to America proves to be anything less than that of a warrior woman.

Scene II is followed by the young girl's move to America, where the narrative communicates a largely different story, one filled with gendered and racialized tensions. As the performance progresses into Scene III: china doll, useless girl, the young Chinese girl moves from China to America. In the performance, I pick up the black tarp filled with dirt and the red tulle and slowly begin my immigration to the United States. The image of me moving around the space, carrying a pile of dirt, is representative of the racist discourse surrounding immigration and immigrant bodies as dirty, devalued, and always "Othered" because of terrestrial links to another land. After the journey to America, I try to straighten out the tarp as it once was in China, however, I cannot manipulate the tarp into a perfect square, foreshadowing the significance cultural "baggage" has in my life in America after immigration. I slowly plant both my feet into the dirt, bury them with my hands, and let the dirt slip out from my fingers while I sit down on the red bench. I begin the scene with the line, "My American life has been such a disappointment." My planted feet in the dirt becomes representative of the notion that the Chinese girl does not belong to an American identity and that her body will always be associated with the dirt the contamination that she came with, a performative discourse that she internalizes. The young Chinese girl fails to perform "whiteness" as a means of belonging and fitting in to hegemonic American culture. As Moreman argues, "whiteness is a performative accomplishment and... acting white as a phrase...signals a collision between history, race, and expectations of cultural performance" (Moreman, 
2009, p. 355). The young girl's negotiation of identity is trapped within the constructs of a "monolithic racial categorization in which all non-white identities are required to forget their connections to anything that is not white" (p. 355). This violent act on the body traps, confines, and binds the body to perform only in specific ways that are accepted and hegemonic. Othered and ambiguous performances of identity are pushed to the margins, bifurcating what is accepted and what is not. Scripting the scenes back to back, illustrates one example of the ways in which "whiteness," the American dream, and immigration are bifurcated and set against each other as opposites. This bifurcation serves to trap performances of immigrant identities in dangerous and problematic ways.

After the young Chinese girl moves from China to the United States, she finds a job in a paint supply store, where the boss charges and powers racist discourses against her.

Order more of that nigger yellow, willya?" the boss told me, "Bright, isn't it? Nigger yellow! "I don't like that word," I said in my bad, small person's voice that made no impact at all. The boss laughed at me as if I were telling a joke. (See Appendix A, p.16-17)

The political undertones in this scene demonstrate one manifestation of the political undertones that fuel racism, bigotry, and cultural hatred for certain immigrant groups. This particular moment and rhetoric in the performance also draws our attention to Bharucha's (2000) notion of language as constitutive of identity. For Bharucha (2000), terms like "multicultural" or "bicultural" operate on performative and strategic levels to first name an identity and then to imbue that identity with marginality, like the term "nigger yellow" in this scene. The language in this particular scene is rife with clandestine racism to historically and publicly mark and "other" the narrator's identity in 
marginalizing ways. In this scene, the young Chinese girl internalizes the discourse of marginality and does not use the tools of her warrior history as a means of transgression, because her cultural history is framed as subpar, illegitimate, and out of context. What worked in China, does not work in America; rather it rendered the young Chinese girl defenseless and in a state of marginality. The racist discourses, in fact, violently mark her body as "Other."

As the scene progresses, the young Chinese girl attempts to resist and reappropriate her gendered and cultural identity. A moment when she successfully resists marginality is when she breaks free from the dirt, kicking it out of her way and refuses to perform the role of a disciplined, docile girl. In that moment, as a performer, I break free from the confines of the dirt and explore empowerment. I continue to move back and forth between the structures of marginality and empowerment, experiencing and exercising moments of transgression. In fact, the young Chinese girl also breaks dishes on purpose, laughing in celebration of her subversion. However, the scene goes on to illustrate that the girl wished she could turn herself into a boy, participating and reaffirming the cultural value of standard gender roles.

I burned the food when I cooked. I do not feed people. I let the dirty dishes rot. I BURNED THE FOOD WHEN I COOKED. I DO NOT FEED PEOPLE. I LET THE DIRTY DISHES ROT! I BURNED THE FOOD WHEN I COOKED. I DO NOT FEED PEOPLE. I LET THE DIRTY DISHES ROT! I BURNED THE FOOD WHEN I COOKED. I DO NOT FEED PEOPLE. I LET THE DIRTY DISHES ROT! I BURNED THE FOOD WHEN I COOKED. I DO NOT FEED PEOPLE. I LET THE DIRTY DISHES ROT! Even now China wraps double binds around my feet. (See Appendix A, p.16) 
This repetition functions initially as a moment of transgression, kicking and moving away from the dirt, but later, this moment manifests into an internalization and disciplinary act of a specific gender role that she cannot escape, pinning her back down into the mud. Lastly, the scene ends with the articulation that the swordswoman and the narrator both have something in common: they both suffer from the violent markings on their skin. They both have so many words that do not fit their skin, but get carved deep within.

\section{Scene IV: Warrior Lessons Magazine Rehab}

In this scene, the text and performance make visible the ironic relationship between empowerment and marginality in the construction of gender. The young girl, after spending some time in America, begins to experience how performing "whiteness" conflicts with performing her Chinese identity, specifically identity as it relates to gender. I begin the scene with the young Chinese girl recalling the story of Fa Mulan, the mythical warrior woman, as a powerful source of identity. In that moment of storytelling, she finds solitude and power in the narrative of the warrior woman, while critiquing the practices of feet binding. When the young girl moves to the United States, she juxtaposes her experiences in China with the stigmatization of America being the land of equality and freedom for all of human kind. The young girl engulfs herself in the mediated images of feminine gender performances that are aggrandized and upheld by hegemonic ideology.

While the narration of Fa Mulan is that of Hong Kingston's words, I interweave my own writing based on the hyper-feminine performance scripts found on magazine 
covers, as a way of offering my own critique of the social constructions of gendered identities within the framework of performing gendered "whiteness." My authorial voice, in this scene, co-communicates with Hong Kingston's to reveal the irony and stigmatization of what is framed as oppressive and empowering. During this scene, the young girl struggles to find home-spaces of identity within both her Chinese and American gendered identities. Both place her body within oppressive constructs of gendered identity.

The scripting and language choices throughout the performance, and specifically, this scene, draw attention to the ways in which language functions as a site of performance with lasting implications. As Moreman argues through J.X. Inda and Butler's work on racial constructs and gender, "over time, the reiterations [of racialized and gendered discourses] bring about a naturalized and normalized effect... on a racialized body" (p. 351) as well as on a gendered body. In Scene IV: Warrior Lesson Magazine Rehab, I draw attention to the rhetorical constructs of gendered identity though the magazine titles as a means of critiquing and providing an alternative, ironic voice that point toward another construct of identity. The ironic critical language framing the scene is a demonstration of reclaiming language as a tactical tool. In addition, the narration of the mythical character, Fa Mulan, in both Hong Kingston's novel, as well as my adaptation, becomes a tactical linguistic and literary choice of reclaiming constructions of identity.

While myths usually have collective significance, the use of the myth in my performance and script functions to communicate an opportunity of adapting and 
rearticulating an alternative identity. The young girl constructs an aspect of her identity based on the warrior woman. Fa Mulan as a source of identity construction blurs the lines between what is considered real and what is considered magic. The magic realism that the mythical figure conjures up, is that of a queer identity, and the ways in which that identity make spaces for other(ed) ambiguous identities in flux. Myths, dreams, and magic are considered by rational discourses make-believe, uncontrollable, and therefore powerful. The magic realism in the script is thus able to challenge notions of reality, specifically the notion of identity construction and the ways in which identity can be challenged and altered. The magic realism in the performance speaks back to the performativity of identity construction, in ways that frame the construction of identity as never "real," "natural," and "normal." In fact, the constructs of identity are always made and remade. Performances of identity, through magic realism, move beyond the power structures of control into spaces of ambiguity and transgression, creating new and empowering spaces within the margins.

In this Scene IV: Warrior Lessons Magazine Rehab, I pick up the red tulle, bind my ankles and begin wrapping my entire body as I seductively utter each of the magazine titles, disciplining myself and my performance of gender into the hegemonic "American" notion of beauty and womanliness. The red tulle ends pressed up against my face, distorting it while I struggle to say the last line, "This freedom feels so good." The red tulle, the text, and my performance of wrapping my body indicate the ways in which gender is circumscribed on the body in problematic and binding ways. The young Chinese girl struggles to negotiate the tensions and stigmas of both Chinese culture and 
feet binding processes as well Western ideologies of womanliness as masquerade. The red tulle becomes a complex tool in the negotiation of tactical responses and strategic structures of power. In effect, I use the red tulle symbolically to challenge, complicate, and question what is regarded as empowering and disempowering as construction of gender is complex, multilayered, and relative.

In this scene, the orchids also perform as a symbol for the socialized construction of the gendered female identity. While the association of women with flowers is nothing new, I make the relationship between the two even more overt in framing the flowers as exotic, vaginal, and grotesque with the sheer number of abundance. The red string from which they hang is symbolic of a violent rendering of the orchid as beautiful, the ways in which my performance explores the same issues of gendered identities and the often violent implications on the body. Like the hanging orchids, my body is bound by the red tulle as my hyper feminine Chinese dress peaks through. I am standing within the hanging orchids, as they engulf my body. Although my body is framed as beautiful in the performance, the text and the performative acts muddle the separation of beauty and pain with bound identity.

\section{Scene V: You Better Talk}

In Scene V: You Better Talk, the performance and text make the hegemonic discourses of cultural identities visible and the ways in which cultural self-hatred is internalized as a strategic mimicry. The politics of mimicry as a strategic tool of oppression are operating as the young girl, living in America now for some time, begins 
to embody and internalize the racist discourse used against her to assimilate and conform. The narrator is asked to show the new and Chinese girl around school. The scene begins with the mother cutting the narrator's tongue as a tactic for being able to speak any language as a means of protection against being "Othered." The narrator internalizes shame and self-disgust as her fails to speak English in ways that are privileged and sanctioned. However, as the narrator finally begins to perform in socially and culturally acceptable ways, she is asked to show the new Chinese girl around school. The narrator tells the audience:

I looked at her and I HATED her. I HATED her silence. I HATED her China doll hair cut. I HATED being seen next to her. I HATED that she reminded me of my own quiet self. Surely the others would remember my own awkward silence. I could not let this happen. (See Appendix A, p.24)

This point in the script exemplifies what Fanon (1963) describes as the internalization of cultural inferiority, to such an extent that the colonized - in this case, the narrator - appropriates the very strategies of cultural inferiority that have been used against her.

As the scene progresses, the narrator, sees herself in the new Chinese girl and does not want to be "Othered" even further. The narrator struggles to find home-spaces of identity, as she is punished for not speaking English as loudly and as perfectly as her classmates do. She is ridiculed and disciplined for the ways in which her body fails to perform an American identity that is accepted and appropriate. The narrator ashamed for her "Othered" identity, has internalized notions of cultural self-hatred, marginality, and inferiority. She then uses the newer younger Chinese girl, who reminds her of herself, as 
a scapegoat to bully and discipline through verbal and physical torment. The main character becomes so enraged with anger, fear, and embarrassment, she begins to bully and discipline the other Chinese girl, not in hopes of helping her, but in hopes of erasing her own "Othered" identity internalizing cultural inferiority, and deflecting those ideologies onto the younger girl. She bullies the other girl as a result of internalizing self hatred, a hatred of the ways in which her body does not perform a Western tongue and a Western notion of femininity.

In that exchange between the girls, the politics of self-internalization of cultural hatred are at play. The main character not only believes the racist rhetoric used to marginalize her sense of self, but sees the other Chinese girl as a despised extension of herself. She, thus, needs to discipline and punish the other girl and herself for their difference. As Moreman states, “...those in societal control force the subjugated to be embarrassed about themselves" (Moreman, 2009, p. 354). The main character sanctions and endorses the racist rhetoric to the extent that she believes that the other girl should be bullied as she was likely bullied.

The operation of oppression between the two Chinese girls is an example of the complicated negotiation of mimicry, reappropriation, and power. In this case, mimicry is not used as a means of reappropriating, challenging, or dismantling the structures of power that control and marginalize the constructions of self; rather, this form of mimicry is used as a strategy, fueling the oppressive structures at hand. The main character became a tool, an extension of the oppressor, positioning herself as both oppressed and oppressor, sustaining the cycle of marginalization, losing her sense of agency. The 
narrator abuses the new Chinese girl as an attempt to empower herself by engaging in a performance of hegemonic disempowerment. The racist language used throughout the scene underscores Moreman's claim that "words can carry pain in their reiterationsspoken not to reclaim an "affirmative resignification" but to continue to produce their harmful and violent effects" (Moreman, 2009, p.354), in this case, the violence of internalization of self hatred for both girls. Mimicry here is a strategy to produce and sustain the marginalized identity. At the moment the narrator employs mimicry to abuse the new Chinese girl, she internalizes the assumptions and discourses of racism and cultural inferiority. The discursive powers in reiterations make me aware of the ways in which my adaptation can implicate, sustain, reveal, and challenge those discursive power structures that I aim to reclaim.

During this scene, I begin to tear down some of the hanging orchids, a physical materialization of the internal hatred the Chinese girl feels about her identity and her performance of it. This scene makes visible what Fanon (1963) describes as the internalization of cultural self hatred in a way that supports the hegemonic structures of marginality. When the narrator yells and screams for the new girl to "talk, talk, talk," the narrator is employing mimicry as a strategy to discipline her own "Othered" body. The moments where I move around the space and tear down the orchids become an attempt to resist the hegemonic discourse of gender and culture which were used to discipline and confine the Chinese girl's body and identity. However, that moment of transgression does not become a successful one because a number of other orchids remain hanging. 
This is indicative of the ways in which attempting to tear down entirely the hegemonic Chinese structures of gender can be difficult, if not impossible.

\section{Scene VI: Tightly Unbound}

My performance script concludes with Scene VI: Tightly Unbound, a moment of self-reflection that is wrapped in contradictions, ambiguity, and a lack of finality. Similar to the other scenes in this performance, the final scene does not offer a concrete ending. I script the ending ambiguously, lacking conclusiveness, to mirror the ways in which stories about immigration and identity construction cannot be limited to the formulaic structures of storytelling. These narratives do not resolve themselves, but rather require a continual process and struggle in finding home-spaces of empowerment and identity. My script resists what Hatcher (1996) argues as being a successful conclusion, an ending that ties up lose ends, shows change and movement in the story and the character, and resists ambiguity. As Hatcher says, "a sense of frustration at the end of a play, by design or error, is worse than a wasted opportunity. The playwright who chooses to frustrate the audience is immature, arrogant, and hostile" (Hatcher, 1996, p. 123-4). Instead, I script the ending with a deliberate ambiguity. I wanted to share a particular narrative, in which a young Chinese girl negotiates the tensions in finding home-spaces of identity. I wanted to script my final scene in a way that communicates my own frustration with a lack of ambiguity for both dramatic endings and identity construction. These narratives of identity construction and immigration are far more complicated and fluid than the rigid and binding arc of storytelling. My script fights against the commodifiable and 
conventional standards of clear narratives. In fact, the lines in the final scene intentionally contradict one another to advance the idea that discourses associated with gendered and cultural identity are never stagnant. My final gesture in performance is where I take the red tulle and I sit down and wrap my body loosely with it. This gesture of enveloping myself with the red tulle, the same red tulle used throughout the performance in often contradictory ways, is a signal to an ambiguous ending. In this final act, the girl reappropriates the symbolism attached to the red tulle as a strategy of oppression, altering it into a tactic of control and assertion in her quest to carve out personal spaces of gender and cultural identity construction.

The textual and directorial choices in my performance help me explore and share a narrative that is deeply complex and ever-changing. The scripting and symbolic choices of my performance garner moments of self-reflection that affirm my perceptions and critical paradigmatic perspectives of identity construction as existing in the spheres of relativism. The symbolic choices throughout the performance help me challenge what I imagined to be possible and move into spaces of a more nuanced understanding of identity construction and its complexities. In staging and performing my critical adaptation of The Woman Warrior, I attempted to explore the negotiations of gender and cultural identity construction of a Chinese American woman, which is fraught with complexity. I attempted to create new and deeper spaces for critical inquiry that examine and draw into question how hegemonic discourses associated with the constructs of gender, culture, and transglobal migration from China to the United States are resisted, internalized, reappropriated, and queered through a live performance. 


\section{CHAPTER FIVE: CLOSING THOUGHTS}

Like the warrior woman in Hong Kingston's novel and my adaptation, I seek to explore the spaces of home, empowerment, and marginality in hopes of better understanding them and their discursive power. I have always felt a strong connection to the novel as I struggled to find voice and agency in my construction of identity. Through the adaptation, I have lived with the struggles of the warrior woman on an intimate and personal level that fuels my passion in retelling this story. I carefully consider the ways in which my adaptation and performance move within the landscapes of bound identity through the retelling of the memoir. As Della Pollock (2008) writes, performance and retelling a story are:

In dialogue thus means engaging in an ethics of thought and relation that may in turn mean intervening in cycles of repetition materialized in performance, and assuming response-ability for the ways in which the story the interviewer-become-narrator tells serves the in-between of all regimes of truth. (Pollock, 2008, p. 124)

Performing and retelling a story has the ability to be in dialogue with the "original" text in ways that encourage more nuanced understandings of identity construction and social action in relationship to those constructions.

I turn to Rivka Eisner's performance, Remembering Toward Loss (2005), a retelling of an oral history memory of her friend Chi Toi, a Vietnamese national. Eisner states that through her performance of Chi Toi, she, “...does not follow traditions of mimetic realism....[but rather]...the performance embodies learning about her life... and in doing so, extend her narrative memory into other's awareness" (Eisner, 2005, p. 123). Mirroring Eisner's approach to oral history performance, my 
adaptation seeks to respect Hong Kingston's memoir, and at the same time, to move to spaces of social action. By sharing the adaptation and performance, I hope to engage with the potential for social action in moving this narrative from the pages of a book to a live performance. The performance event, my performing body, the audience's varied perspective and the text itself come together in a dialogical performance and conversation to make spaces for the ambiguity of identity. In doing so, the performance and adaptation moves beyond the realms of the stage and the page, aiming for social efficacy and critical engagement.

In many ways, the performance is about a young Chinese girl who does not successfully find empowering home-spaces of gendered and transcultural identity. The young Chinese girl negotiates the tensions of the often complicated processes of identity construction that can be binding and marginalizing. Although this is very much a painful story of identity, it is also a story about recognizing and revealing the social structures that sustain and produce those processes of pain. Throughout the performance, I find moments to critique, challenge, and reappropriate the performances of marginality into performances of empowerment. With Eisner in mind, the goal of my performance is to re-story in hopes of moving "towards something more than repetition...to speak [about] memories, experiences, and voices into renewed significance, [and] moving into uncharted territories in the hopes of opening up spaces of learning and possible transformation" (p. 124). I am unsure what those spaces are and what they look like, but to possibly move into the realm of social engagement and social action is a worthwhile goal of performance. As Eisner puts it, "To cover over the 'wounds' of history, to try to 
fix them, or even simply to expose them to anything like sensational voyeurism... would be acts of violence in their own right" (p. 124). Therefore, the performance of literature, memoirs, and memories, even when painful, can be a necessary step in the movement toward social change.

After the second performance night, a friend of mine wrote me an email sharing with me her thoughts on my performance. She talked about what she particularly liked and what moved her specifically. She said that the performance had a sense of transparency, where the lines between the character and me were blurred and ambiguous. Her comment underscored the notion that, while literature may exist in the realm of fiction, it has real life implications and consequences. Between the text, the author, the narrator, the performer, and the audience, my adaptation of the novel aimed to form a sort of partnership amongst each of those relationships as a means of engaging with Conquergood's (1985) “dialogical performance,” texts, people, and cultures speaking with each other rather than for one another.

In January 2010, I was invited to perform at an academic retreat on immigration organized by the Silicon Valley Center for Global Innovation and Immigration and held in Pacific Grove, California, for a group of scholars in fields concerned with the social, cultural, and political aspects of immigration. I presented a shortened version of my thesis performance that included Scene I: no name woman, Scene IV: Warrior Lessons Magazine Rehab, and Scene V: You Better Talk. In the question and answer session after the performance, Dr. Ruth Wilson, Chair of the African American Studies Department at San José State University, said that the performance illuminated something 
she had always felt as a child, but had not quite understood. An African American born in the south of the United States, Dr. Wilson moved with her family to California as a young girl. She said that other African American children would tease and bully her about her southern accent. At the time, Dr. Wilson said she could not understand why the other children were so mean; she assumed that they were just engaging with child's play. Dr. Wilson said that Scene V: You Better Talk, the one in which the narrator internalizes cultural inferiority and takes it out on the new Chinese girl, informed her experiences of growing up with other African American children in California who teased her about her southern accent. The performance materialized what Fanon (1963) calls "colonial domination," which dangerously and profusely manifests in exchanges of internalization of cultural self-hatred. I am grateful for Dr. Wilson's warm remarks, but I am even more appreciative and fortunate to see how performance might live and move into the lives of people as a means of self-reflection and compelling consideration.

This thesis project has been a challenging and rewarding journey. Through scripting and performing a critical adaptation of Maxine Hong Kingston's The Woman Warrior, I have encountered performance in new ways. Performance, as a tool and as a paradigmatic perspective, helps me explore the processes of resistance, reappropriation, and queering my body as a means of tactically responding to hegemonic structures and discourses of control. Performance functions as an act towards social justice and action, specifically in creating spaces for ambiguous identities. As Pollock puts it, "performance goes beyond representation into transformation, beyond mirroring into witnessing and [beyond a simple] translation [into] response-ability" (Pollock, 2008, p. 132-133). At its 
best, live performance moves beyond the passive speculation of stories into the possibility for action and reappropriation in our lives.

While I was scripting and rehearsing scenes, there were a number of moments where I felt I was engaging in messy and uncomfortable territory, territory that implicated my own history, informing my own notion of gender and cultural identity. Goldman paraphrasing Renato Rosaldo suggests that “culture's richest meanings emerge when we are in motion, operating dynamically and often messily from inside the fray of culture" (Goldman, 2006, p. 370). In the process of rehearsals, I found myself unexpectedly stirred by a particular scene that made visible the ways in which language imbues performances of culture and identity. Although, I had scripted the text, memorized it, and knew what to expect, during a rehearsal night, after the "nigga yellow" scene, I started crying. My chest felt heavy and I paused for a couple seconds, uncomfortable and unsure of what to do next. After I regained my sense of direction, I continued on with the scene, but I had experienced performance in a new and deeper way. While the language in that scene is agonizing and monstrous to articulate, I already knew what to expect given that I had scripted it myself. But in that moment of performing that language and bringing it to life, I inflicted it onto my body, reliving that moment in the memoir of abuse, pain, and oppression. While I understand the concepts of oppression and the structures of marginality in my life, the performance revealed the structures of pain and oppression in such a physical and bodily way. I cannot claim to understand completely the world in which the narrator of Maxine Hong Kingston's novel lives, but I can acknowledge and 
respect the struggles and the ways in which this story is made very real in the lives of other people who share in those moments of oppression.

Scene IV: Warrior Lessons Magazine Rehab was another place that was particularly painful and unnerving for me. While I was scripting and rehearsing that scene, I felt conflicted and uncomfortable as I began to articulate my own struggle with performing gender. In that scene, I critically name the ways in which gender is marked on a woman's body and how it is performed in marginalizing ways. However, as I began scripting that scene, I thought of the politics of my own body, my performance of gender, and how I strategically and tactically participate with those structures. In implicating my own history and identity, I faced several fears, which I had previously avoided. I draw upon hegemonic discourses and performances of gender to inform my own body politics. I willingly participate in the processes of marking my body as feminine, sexual, and womanly, much like that of the magazine titles I call out and critique. And I have always felt that my participation in those sanctioned performances of gender would also doubly mark me as dumb and worthless in the context of the academy. I felt embarrassed about the way I choose to look and a coward for not doing anything about it. However, as Goldman puts it:

The adaptation and staging [of a text is], among other things, an attempt to create a new space. The rhetorical power of this space emerged largely from the fact that the space carved out by [the text] was simultaneously operating in three terrains...the physical, the mental, and the social. (Goldman, 2006, p. 371)

And in scripting and performing that scene, I entered a "new space" that interrogated the tensions the power structures that I felt. That moment in the performance became a 
moment of reappropriation and empowerment, in that I am aware of the structures that I participate in and I control the performances of my gendered identity. I inhibit a borderland existence, like Anzaldua (1987), where I can tactically negotiate and queer performances of my identity that are seemingly contradictory in relationship to hegemonic discourses and move towards the direction of ambiguity and freedom.

Critical adaptation is more than a reinterpretation of novel; for me it is a metaphor for living. Engaging in a critical adaptation has been both cathartic and uncomfortable, empowering and distancing, all of which were vital to my journey and process of exploring hegemonies of gender and cultural identity. As Goldman says:

To teach adaptation is to riff on any number of binary divisions that have characterized double-consciousness in the American cultural imagination, such as those between the teacher who knows and the student who learns, artistic and intellectual production, oral interpretation and performance studies, cultural politics and aesthetic practice. Understood in this way, adaptation may be a crucial means of dismantling and reinventing power structures that those binaries have held in place. (Goldman, 2006, p. 377)

In riffing off Goldman, critical adaptations of literature have the potential to become discursive spaces for creating meaning rather than simply finding them. Therefore, critical adaptation might be something of a metaphor for social and cultural life and our performances of identity. The complexity of critical adaptation mirrors our own navigation of identity in the social world, in which we are constantly required to negotiate our multiple and sometimes contradictory identities in tactical and strategic ways. And in much the same way, a scriptwriter of an adaptation must navigate the text of a novel. 
THE WOMAN WARRIOR SCRIPT 


\section{The Woman Warrior}

Adapted for the stage by Julia Salvador

Based on the novel by Maxine Hong Kingston

Performed in Hugh Gillis Hall, Room 231

San José State University

November $5^{\text {th }}, 6^{\text {th }}, 7^{\text {th }} 2009$ 
The Woman Warrior 11-04-09, adapted by Julia Salvador

\section{Scene I: no name woman}

(The stage is set with a red cloaked bench center stage with a black rectangular tarp in front of it on the floor. On the bench sits a bundle of red tulle, a red egg, and a red dog collar. Directly above the red cloaked bench are seventy six individually hung pink, white, and green orchids. The orchids are hung with red string from the ceiling to the petal. The audience is set up in a semicircle, ten feet away from the red cloaked bench, with a walkway down the center. The lights are out. 願君心記取 “I Hope Your Heart Remembers Me" traditional instrumental Chinese music is playing, a red spotlight shines center stage and a woman, dressed in a green Chinese dress, slowly walk upstage, through the walkway, passing the audience to the bench. The woman 
The Woman Warrior 11-04-09, adapted by Julia Salvador slowly picks up the bundle of red tulle, examines it, shows the audience, and then places it on the black tarp. The woman picks up the red dog collar, examines it as well, shows the audience, and places it on the black tarp. She picks up the red egg, shows the audience and holds it out in front of her. The music fades out.)

\section{SHE}

My mother said, "You must not tell anyone what I am about to tell you. In China your father had a pregnant sister who killed herself. She jumped into the family well. We say that your father has all brothers because it is as if she had never been born. Your aunt could not have been pregnant, you see, because her husband left for the army two years ago. She gave birth in the pigsty that night like an animal. The next morning when I went for water, I found her and the baby plugging up the family well. Don't let your father know that I told you. Now that you have started to menstruate, what happened to her could happen to you. Don't humiliate us. You wouldn't like to be forgotten as if you had never been born."

(She crushes the red egg in front of her, letting the pieces fall to her feet. She picks up the red dog collar and put it on her neck.) 
The Woman Warrior 11-04-09, adapted by Julia Salvador

SHE

My mother had told me once and for all the useful parts about who I should be in the world through the telling of my aunt's story.

(She attaches the red tulle to the red dog collar like a leash, holding one end of the tulle.)

SHE

She will add nothing unless powered by Necessity, a riverbank that guides her life.

Women must be precise and only speak the necessities, nothing more.

She planted vegetable gardens rather than lawns; carried odd-shaped tomatoes home from the fields and ate food left for the gods.

Because to be a woman, to have a daughter in starvation time, was a waste enough.

But the story that my mother told me about my aunt wasn't enough for me!

My aunt could not have been the lone romantic who gave everything up for sex.

Some man must have commanded her to lie with him and be his secret evil.

(She picks up the red tulle, goes to the bench and get on her knees, with her butt sticking out, and pulling the tulle back like a leash.)

SHE

His demand must have surprised, and then terrified her. 
The Woman Warrior 11-04-09, adapted by Julia Salvador

(She gets off the bench and stands in front of

it.)

\section{SHE}

My aunt obeyed him; she always did as she was told.

(Facing the audience, the woman sits on the

bench, leans back and spreads her legs open

as she drops the rest of the red tulle in

between them.)

SHE

The other man was not, after all, much different from her husband you see. They both gave orders: she followed.

(She stands up and delivers line in a deep voice.)

SHE

He said "Be here again next week. If you tell your family, I'll beat you. I'll kill you." She told the man, "I think I'm pregnant."

(She picks up the bundled red tulle and pulls it up to her stomach to indicate a pregnant body.) 
The Woman Warrior 11-04-09, adapted by Julia Salvador

SHE

He organized a raid against her. The raid was justified because this extra child would cause hardship for the whole community. Selfish, Selfish, Selfish woman.

Or maybe, just maybe, my aunt fell in love.

(She pulls the tulle off and drops it on the black tarp. The woman moves down stage left and takes the collar off and drops it as well.)

SHE

Maybe she wasn't raped at all. She was after all a very beautiful woman.

(Moving back to center stage, the woman mimics the touching of her hair behind her ears and the question mark line on the torso.)

SHE

Maybe she liked the way his hair was tucked behind his ears or she liked the questionmark line of the long torso curving at the shoulder and straight at the hip.

For warm eyes or a soft voice or a slow walk-that's all- a few hairs, a line, a brightness, a sound, a pace, she chose to give up family.

She chooses herself. 
The Woman Warrior 11-04-09, adapted by Julia Salvador

(She looks over the audience's head as if to see the man and wanting him to look back as her.)

SHE

She looked at him and wanted him to look back.

At the mirror my aunt combed individuality into her bob.

(She touches her hair.)

\section{SHE}

I hope that the man my aunt loved appreciated a smooth bob, that he wasn't just a titsand-ass man.

Once, my aunt found a freckle on her chin, at a spot that the almanac said predestined her for unhappiness.

(The woman picks out the freckle on her chin with confidence.)

SHE

She dug it out with a hot needle.

All the attention to her looks, the shaping of hairs and picking of spots would have caused gossip among the villagers.

(She moves back to down center stage in front of the walkway facing the audience.) 
The Woman Warrior 11-04-09, adapted by Julia Salvador

SHE

They said "She must have wanted men who were not her husband to look at her."

She was always at fault.

(She picks up the red tulle and slowly wraps it back into a bundle.)

\section{SHE}

She kept the man's name to herself throughout her labor and dying, as if she was proud to have a secret.

The villagers punished her for having a private life, secret and apart from them. Instead of letting the disappointments and outcasts start separate new lives like the Japanese, who could become samurais and geishas, the Chinese family, faces averted but eyes glowering sideways, always hung on to the offenders and fed them leftovers.

(She put her head down and scans the audience from right to left with just her eyes. She grabs the red tulle and pulls it back to her stomach, and holds her stomach as if in pain.)

SHE

When she felt the birth coming, she felt the pain of the child in her. 
The Woman Warrior 11-04-09, adapted by Julia Salvador

(Holding her stomach in pain, she runs upstage right backwards to the corner of the room.)

SHE

She ran out into the fields, far from the house and pressed herself against the earth, her own land no more.

She rose to her feet to try to fight and remembered that old-fashioned women once gave birth in pigsties to fool the jealous, pain-dealing gods who did not snatch up little piglets.

(The woman runs upstage center, directly behind the red bench and presses herself against the wall.)

SHE

She ran into the pigsty.

She climbed over the fence and knelt in the dirt.

(She looks up at the orchids.)

SHE

It was good to have a fence enclose her, a tribal person alone at last!

(With knees slightly bent and body pressed up against the wall, the woman throws the 
The Woman Warrior 11-04-09, adapted by Julia Salvador red tulle away from her stomach to the floor, behind the red bench.)

\section{SHE}

Laboring, she finally expelled it.

(Slowly and hesitantly, she picks up a yellow flower pot filled with dirt and a single stemmed orchid from behind the red bench.)

\section{SHE}

And when she reached down to touch the hot, wet, moving mass, surely smaller than anything human, she realized and could feel that it was human after all - fingers, toes, nails, and nose.

(The woman slowly walks from behind the bench with the yellow flower pot to the center stage in front of the bench. She pulls the flower pot to her belly, caressing it and lovingly looking at it.)

\section{SHE}

She pulled it up to her belly and it lay curled there, butt in the air, feet precisely tucked one under the other. 
The Woman Warrior 11-04-09, adapted by Julia Salvador

(She mimics loosening up her shirt and pulls the flower pot up to her breast.)

\section{SHE}

She opened her loose shirt and pushed it up to her breast.

It found her nipple and she clenched her teeth at its preciousness, lovely as a young calf, a piglet, a little dog.

(She gently rocks the yellow flower pot back and forth.)

SHE

She may have gone to the pigsty as a last act of responsibility: she would protect this child's identity.

It could perhaps look after her soul, leaving supplies on her grave.

But how would this tiny child without family find her unmarked grave?

(Disappointed, she puts the yellow flower pot down on the ground in front of her feet.)

SHE

She realized at its birth, she had taken the child with her into the wastes.

A child with no descent family line would follow her around, ghostlike, begging her to give it purpose.

Full of milk, the little ghost slept. 
The Woman Warrior 11-04-09, adapted by Julia Salvador

(The woman picks up the yellow flower pot and slowly walks upstage left towards the bench.)

SHE

When it awoke in the morning, she picked up the baby and slowly walked to the well. Carrying the baby to the well shows love.

Otherwise abandon it.

(She stands up on top of the red bench with the yellow flower pot resting in her arms.)

\section{SHE}

Turn its face into the mud.

Mothers who love their children take them along into the well.

It was probably a girl; there is always some hope of forgiveness for boys.

(She holds the yellow flower pot above her head and dumps out the flower and the dirt on the black tarp on the ground. She slowly gets down from the bench and sits down on the bench facing the audience.)

If I wanted to learn more about my aunt, I would have to begin, "Remember Father's drowned-in-the-well sister?"

But, I cannot ask that. 
The Woman Warrior 11-04-09, adapted by Julia Salvador

(The same Chinese music track from the beginning of scene one plays again and she looks at the orchids above her head.) 
The Woman Warrior 11-04-09, adapted by Julia Salvador

\section{Scene II: MAD SWORDSWOMAN}

(The woman stands up in front of the bench and puts the flower pot down on her left. She stands center stage with legs spread apart over the spilled dirt. The Chinese music fades out.)

\section{SHE}

When we Chinese girls listened to the adults talk story, we learned that we failed if we grew up to be but wives or slaves.

We could be heroines, swordswomen.

Even if we had to rage all across China, a swordswoman got even with anybody who hurt her family

Perhaps women were once so dangerous that they had to have their feet bound.

It was a woman, you know, who invented white crane boxing. She was combing her hair one morning when a white crane appeared outside her window.

(She steps forward and tries jabbing the air towards her left. Then, she moves her arms in a half circle counter clock wise, starting at 
The Woman Warrior 11-04-09, adapted by Julia Salvador

her knees moving towards her head to imitate a brush of a crane's wing.)

\section{SHE}

She teased it with her pole, but the crane pushed it aside with a soft brush of its wing.

(She leaps forward trying down center stage

left jabbing the air once again.)

\section{SHE}

Amazed, she dashed outside and tried to knock the crane off its perch.

(With both her arms, she imitates breaking a pole in half, starting with her hands above her head and moving them down to her hips.)

\section{SHE}

But it simply snapped her pole in two.

Recognizing the presence of great power, she asked the spirit of the white crane if it would teach her to fight. The crane quickly turned into an old woman and guided her boxing for many years.

Night after night my mother would talk-story like this one until I fell asleep.

This was one of the tamer, more modern stories, a mere introduction.

I couldn't tell where her stories left off and my dreams began. 
The Woman Warrior 11-04-09, adapted by Julia Salvador

(The red spotlight fades out and a white spotlight fades in. Dream like music plays while the woman walk to the back of the bench and pick up the red tulle. She stands up on top of the bench with red tulle in one hand while the other parts open a section of the orchids.)

\section{SHE}

The door opened and an old woman came out carrying bowls of rice and peaches.

(The woman steps down from bench and places bundled red tulle down center stage right on the ground.)

\section{SHE}

She greeted me, "have you eaten rice today, little girl?"

"Yes, I have, thank you."

I would have said in real life, "No, I haven't," mad at the Chinese for lying so much.

"I'm starved. Do you have any cookies? I like chocolate chip cookies."

"I was about to sit down to another meal," the old woman said. "Why don't you eat with me?"

When the mountains and pines above us turned into blue oxen, blue dogs, and blue people, the old woman asked me to spend the night in the hut and I did. 
The Woman Warrior 11-04-09, adapted by Julia Salvador "Little girl, you have now spent almost a day and a night with me," the old woman said. "Do you think you can bear to stay with me for fifteen years? I can train you to become a warrior."

I thought about my mother and father harvesting sweet potatoes and how I had dreamed of becoming a warrior, to avenge my village, to recapture the harvests the thieves had taken.

(The woman moves her arms up and down her sides, perched on one leg, like a flying crane. She continues flying down stage left.)

SHE

So I decided to stay and instantly the old woman turned into a crane.

For fifteen years I learned how to live amongst the animals, learned their lessons of both hiding and fighting, skills a warrior can use.

(She continues flapping her arms upstage right.)

SHE

I learned to see without my eyes, to feel without my hands, to stay full without food, to be a warrior, a woman warrior. 
The Woman Warrior 11-04-09, adapted by Julia Salvador

(Moving back center stage, she picks up the yellow flower pot and shakes it while she looks down into the bottom.)

\section{SHE}

And when I missed my family, the crane took out a water gourd and shook it until I saw my family appear in the reflection at the bottom of the gourd.

One day, I saw my mother and father speaking to a General of the Chinese army.

The General said, "Your baron has pledged me fifty men from this district, one from each family."

(She yells into the pot.)

\section{SHE}

"No!" I screamed into the gourd as I heard my dying father's name being called.

I have to go I yelled to the crane; I have to save my father.

And with that I prepared my things and left.

I returned to my village to take my father's place in battle.

Before I could leave home, my mother put a pillow on the floor before the ancestors.

(Picking up the bundled red tulle the woman walks to the bench and kneels on it with her back facing the audience. She holds one end of the red tulle and lets the other end roll down her back from her head to her feet.) 
The Woman Warrior 11-04-09, adapted by Julia Salvador

SHE

"Kneel here," she said. "Take off your shirt. We are going to carve revenge on your back."

(She gets on top of the red bench.)

\section{SHE}

As she carved, the crimson blood dripped down my back and soaked the white pillow beneath me.

(She drops the tulle on the ground, gets up from the bench facing the audience. She reaches down into the dirt, grabbing some and rubbing it on her facing making a line under each eye, as if to mark her face with war paint.)

SHE

I put on men's clothing and armor and tied my hair in a man's fashion.

(She moves down stage left and back stage right slowly and hunched over, spy like.)

\section{SHE}

And for two years, my squad didn't know who I was.

I had become an expert trickster, to protect my identity and give me power. 
The Woman Warrior 11-04-09, adapted by Julia Salvador When I became pregnant, during the last four months, I wore my armor altered so that I looked like a powerful, big man.

(She pushes her chest out forward and broadens her shoulders. She moves back to center stage and touches her back with one arm and touches her stomach with the other.)

\section{SHE}

But when I was naked, I was a strange human being indeed—words carved on my back and the baby large in front.

(She says the following lines in a low voice with pelvis pushing back and forth.)

\section{SHE}

When I captured the enemies and they wanted to appeal to me man to man, they would say, "Oh come on now. Everyone takes the girls when he can. The families are glad to be rid of them. Girls are maggots in the rice; it is more profitable to raise geese than daughters."

(She pulls her hair down from a pony tie.) SHE

And before I would behead my enemies, I pulled down my hair to show them who was going to take their lives. 
The Woman Warrior 11-04-09, adapted by Julia Salvador

(Standing center stage, three feet away from audience, the woman brings her hands together as if to make a sword and slices the air with it.)

SHE

I yelled at the top of my lungs, "I AM A FEMALE AVENGER!" and sliced with my sword.

Then I left China for America!

(The red light fades back in and Neil

Diamond's "They're Coming to America" plays loudly, while the woman picks up the yellow pot and places it on the left side of the bench not on the black tarp. With energy and excitement she picks up two corners of the black tarp and starts to drag it upstage left to the corner of the room, while the pile of dirt, the red tulle, the broken flower, shattered egg shells and the red dog collar lay atop it. Once she reaches the left hand corner, the woman catches her breath and brings the journey once more to the 
The Woman Warrior 11-04-09, adapted by Julia Salvador upstage right hand corner. When she reaches the right hand corner, she is exhausted and begins to show struggle as she treks back center stage. Once reaching center stage, she positions the black tarp back in front of the red cloaked bench, straightening out the sheet. Standing right in front of the bench, she buries her feet into the dirt, and with her hands, picks up the dirt, letting it slip out of her fingers falling to her feet while she brings her hands up to her waist. The music fades out and she sits down on the bench with her feet planted in the dirt.) 
The Woman Warrior 11-04-09, adapted by Julia Salvador

\title{
Scene III: china doll, useless girl
}

\begin{abstract}
SHE
My American life has been such a disappointment.

"I got straight A's, Mama."

"You can't eat or save with straight A's," she'd say.

(The woman rocks back and forth violently

while sitting down on the bench.)

\section{SHE}

When one of my parents or the emigrant villagers said, "Feeding girls are feeding cowbirds," I would thrash on the floor and scream so hard I couldn't talk. I couldn't stop. "What's the matter with her?"

"I don't know. Bad, I guess. You know how girls are. There's no profit in raising girls. Better to raise geese than girls.”
\end{abstract}

(She stands up from the bench with her feet still planted in the dirt.)

\section{SHE}

When I went away to college-Berkeley in the sixties-I studied and I marched to change the world, but I could not change myself into a boy. 
The Woman Warrior 11-04-09, adapted by Julia Salvador

I would have liked to bring myself back as a boy for my parents. Instead I was a girl who got straight A's.

There is a Chinese word for the female, "I"-which is "slave." The Chinese want to break the women with their own tongues!

(Standing up, the woman takes two large steps out of the dirt.)

SHE

I refused to cook. And when I had to wash the dishes, I would crack one or two on purpose.

"BAD GIRL," my mother yelled, and sometimes that made me happy rather than cry. Isn't a bad girl almost a boy?

(She starts off slowly whispering the lines below while walking out into the audience, looking directly into their eyes. She increasingly says the lines louder and louder walking back to center stage. Then she begins yelling the lines out faster and faster, pacing from center stage left to center stage right, screaming the lines below, until she suddenly stops dead center.) 
The Woman Warrior 11-04-09, adapted by Julia Salvador

SHE

I burned the food when I cooked. I do not feed people. I let the dirty dishes rot. I

BURNED THE FOOD WHEN I COOKED. I DO NOT FEED PEOPLE. I LET THE

DIRTY DISHES ROT! I BURNED THE FOOD WHEN I COOKED. I DO NOT FEED

PEOPLE. I LET THE DIRTY DISHES ROT! I BURNED THE FOOD WHEN I

COOKED. I DO NOT FEED PEOPLE. I LET THE DIRTY DISHES ROT! I

BURNED THE FOOD WHEN I COOKED. I DO NOT FEED PEOPLE. I LET THE

DIRTY DISHES ROT!

Even now China wraps double binds around my feet.

(The woman grabs yellow ribbon from

under the red cloaked bench hiding it in her

palm.)

SHE

Once I worked at an art supply store that sold paints to artists.

(Holding one end of the yellow ribbon, she

lets the other end unravel down to the

ground in front of her.)

SHE

"Order more of that nigger yellow, willya?" the boss told me "Bright, isn't it? Nigger yellow!" 
The Woman Warrior 11-04-09, adapted by Julia Salvador

(She wraps yellow ribbon over her shoulders.)

\section{SHE}

"I don't like that word," I said in my bad, small person's voice that made no impact at all. The boss laughed at me as if I were telling a joke.

(Picking up one end of the red tulle, the woman grabs the other end and stretches it out to resemble a sword.)

\section{SHE}

I wish I could take a sword, which my hate forged out of thin air, and gut him; then I would put the color yellow all over his shirt.

(She drops one end of the red tulle.)

\section{SHE}

But I didn't.

(She drops the other end of the red tulle, letting it fall to the ground.)

\section{SHE}

I am not a female avenger. How could I? Because I spoke funny, looked funny, I did not belong in this land.

I once saw a crane and chased after it, but soon realized it was just a seagull. The swordswoman and I are not so dissimilar though. 
The Woman Warrior 11-04-09, adapted by Julia Salvador What we have in common are the words on our backs. And I have so many wordsnigger yellow words — chink words—gook words—woman slave words, that do not fit on my skin, but somehow get carved deep within.

(換到千般恨 “One Thousand Exchanges of Rooted Hatred," traditional instrumental Chinese music fades in loudly. The woman stands center stage while she rewraps the red tulle into a bundle. She carries the red tulle with her as she steps atop the red cloaked bench. She turns and faces the audience. She strikes an awkward model pose with her knees bent, butt sticking out, mouth covered, and eyes closed. She then grabs one end of the red tulle and ties it around her ankles. The music fades out.) 
The Woman Warrior 11-04-09, adapted by Julia Salvador

\title{
Scene IV: Warrior Lessons/Magazine Rehab
}

\author{
SHE \\ When we Chinese girls listened to the adults talk story, we learned that we failed if we \\ grew up to be but a wife or a slave. \\ We could be heroines, swordswomen. \\ Even if we had to rage all across China, a swordswomen got even with anybody who hurt \\ her family. \\ Perhaps women were once so dangerous that they had to have their feet bound. \\ When my family and I moved from China to America, my mother said that I would know \\ what it would feel like to be free, to not have our feet bound at the age of seven. \\ To not have to sit in bed all day long and cry together with sisters, as mothers removed \\ the bandages for a few minutes each night and let the blood gush back into veins as their \\ feet begin to curl and bend. \\ In America, I was told that women were not dangerous, not bounded. \\ We could live the American dream. \\ I was told we could be independent, freethinking, strong, and powerful. \\ We did not have to become but a wife or a slave. \\ I was free to become the heroine, the swordswomen. \\ My heroine training began immediately.
}


The Woman Warrior 11-04-09, adapted by Julia Salvador

(The woman picks up the red tulle and begins wrapping her entire body as she says each of the lines below. Each line is said in a seductive like manner while directly looking at one audience member per line.)

\section{SHE}

My lessons included:

15 date ideas he'll be into.

How long guys want sex to last.

How to be bitchy just enough.

The Man Manual. Get all you need to know to satisfy him now!

If he stops wanting sex, something is wrong.

Is your hair as hot as it could be?

Today's the day to entice.

(She tightens the red tulle at her thighs.)

Fun fearless fashion, tighten those thighs.

Beginner Botox: are you ready to commit?

Hot tips, products and tricks

No fail workouts for your butt and your brain.

The sex quiz you must take. 
The Woman Warrior 11-04-09, adapted by Julia Salvador

(She tightens the tulle at her stomach.)

\section{SHE}

Lose your belly in just 12 days.

14 amazing sex secrets, use em or lose him!

Do you know your happy weight?

Make him a meal he'll devour: these man friendly dinner recipes will wow your guy.

10 self checks to do before breakfast.

Younger smoother skin.

Beauty bummer, we'll solve it!

Eat what you crave and still lose weight.

11 things every guy wants from a woman.

(The red tulle is around her entire body including her face, distorting it. As she tightens the tulle around her face, she struggles to, but again seductively, says the last line.)

SHE

This freedom feels so good.

(換到千般恨 “One Thousand Exchanges of Rooted Hatred," Chinese music fades back in.) 
The Woman Warrior 11-04-09, adapted by Julia Salvador

\section{Scene V: You Better Talk}

(The woman slowly unwraps the red tulle from her entire body. Once the red tulle is off, she places it on the bench and walks upstage left corner and picks up a black leather jacket and lipstick. She walks back to center stage, places the black leather jacket on the bench and picks up the red lipstick. She sticks out her tongue and marks a line down the middle of it and down her neck with the red lipstick. She drops the lipstick on the black tarp and plants her feet back into the dirt, picking up handfuls of dirt and letting it slip from between her fingers back down to the ground. She looks up and the music fades out.)

\section{SHE}

My mother cut my tongue when I was young.

I don't remember her doing it, only her telling me about it. 
The Woman Warrior 11-04-09, adapted by Julia Salvador

She did this after we moved from China to America.

Sometimes I felt very proud that my mother committed such a powerful Chinese act upon me.

At other times I was terrified - the very first thing my mother did when she saw me was to cut my tongue.

"Why did you do that to me, ah-ma?"

"Tell me again."

She said she cut it because she did not want me to be tongue tied.

She wanted my tongue to be able to move in any language.

So that I would have a ready quick tongue.

The Chinese say a ready tongue is an evil.

"Things are different in this ghost country, you need a ready quick tongue!" she said.

Sometimes at school I wished she had cut it all away!

When I went to kindergarten and had to speak English the first time, I became silent.

(The woman pushes her finger down her lips and neck smearing the red lipstick.)

\section{SHE}

A dumbness - a shame - cracked my voice in two, when I just wanted to say "hello" or ask a simple question.

I stood frozen.

"What did you say?" teachers and students would ask. 
The Woman Warrior 11-04-09, adapted by Julia Salvador

"Speak up!" they would yell.

So I did, but always weaker the second time.

Responses in the classroom made my throat bleed and took up the whole day's courage.

It spoiled my day with self-disgust when I heard my broken voice come skittering out into the open.

(She covers her ears violently.)

\section{SHE}

It made people wince to hear it.

You could see the disgust on American faces looking at me when I spoke with my broken quiet English and perfect loud Chinese.

It wasn't just that it was loud...

(She slants her eyes back with both her fingers.)

SHE

It was the way Chinese sounds, Chingchong ugly, to American ears, not beautiful like Japanese sayonara words with consonants and vowels as regular as Italian.

We make guttural peasant noises and have Ton Duc Thang names Americans can't remember.

(She slowly steps out of the dirt while kicking some up.) 
The Woman Warrior 11-04-09, adapted by Julia Salvador

SHE

I was slowly improving, making progress, a little every day.

And after a while, people forgot that I had trouble speaking English.

My accent slowly disappeared.

I was no longer known as the weird CHING-CHONG Chinese girl.

(The woman picks up the black leather jacket and puts it on.)

SHE

One afternoon in the sixth grade, I was asked to stay after school with a new quiet

Chinese girl, to show her around campus.

I looked at her and I HATED her.

I HATED her silence.

I HATED her China doll hair cut.

I HATED being seen next to her.

I HATED that she reminded me of my own quiet self.

Surely the others would remember my own awkward silence.

I could not let this happen.

(While the woman moves slightly stage left, she stomps on the ground and turns back to center stage, in front of the dirt.) 
The Woman Warrior 11-04-09, adapted by Julia Salvador

SHE

So I started to show her around and our first stop was the bathroom.

I stopped abruptly in front of the sinks and she collided into me.

(The woman turns around and yells out the

lines below to one focal point slightly above

the audience.)

SHE

I turned around and said, "You're going to talk!"

"I'm going to make you talk, you sissy-girl."

She backed away and stood fixed.

I looked into her face so I could HATE it close up.

“Talk," I said.

“TALK," I shouted!

“Say Hi” I said.

"Go ahead and say your name! Or are you stupid?"

"Your soooooo fucking stupid! You don't even know your own name!"

Her eyes dripped, her nose dripped.

I grabbed her and said.

(The woman begins by saying the lines quietly and then she says them increasingly louder and faster. As she says the words 
The Woman Warrior 11-04-09, adapted by Julia Salvador

louder and faster, she turns around and walks towards the hanging orchids and continues to yell the lines below while ripping down the orchids. She moves from behind the red cloaked bench back to center stage from right to left, dropping the orchids on the ground.)

SHE

“talk, talk, talk, talk, Talk, Talk, Talk, Talk! Talk! Talk! Talk! TALK! TALK! TALK!

TALK! TALK! TALK! TALK! TALK! TALK! TALK! TALK! TALK! TALK!”

(While standing center stage, she pauses for a moment.)

SHE

The only sounds that came out of her mouth were sobs, chokes, and noises that were almost words.

(She rubs and smears the red lipstick all over her face.)

SHE

Her eyes kept dripping, her nose kept dripping.

She tried to wipe it off with her hands, but there was too much of it.

"You are so disgusting and shameful!" I yelled. 
The Woman Warrior 11-04-09, adapted by Julia Salvador

“Why won't you talk?” I said quietly.

I started to cry.

Her sobs and my sobs were bouncing wildly off the ground.

"You're in America; now you better talk!"

(換到千般恨 “One Thousand Exchanges of

Rooted Hatred," traditional instrumental

Chinese music fades back in as the woman

takes off the black leather jacket and stands

on top of the red cloaked bench facing the

audience.) 
The Woman Warrior 11-04-09, adapted by Julia Salvador

\section{Scene VI: Tightly Unbound}

(Chinese music fades out.)

\section{SHE}

You must tell everyone that you know what I am about to tell you!

I am nobody's China doll.

I made myself unsellable and I am enjoying every second of it.

I said fuck putting tape over my "chinky" eyes to make eyelids like American faces.

My sexuality does not begin with the order of a command.

When I am naked I am a beautiful woman.

I can wear my jade necklace, blue jeans, and bra all at once and love feeling bound and empowered at the same time.

(The woman grabs the yellow ribbon from

her shoulders and throws it on the floor.)

SHE

Nobody paints my body "nigger yellow."

"Asian" does not mark my body.

When I talk story the beginning is sometimes my mother's and the ending is sometimes mine.

(Chinese music fades in as underscore.) 
The Woman Warrior 11-04-09, adapted by Julia Salvador

SHE

I forget the color of my skin.

I never forget the color of my skin.

I masquerade as "woman."

I unmasquerade as "woman."

I lose my voice.

I never lose my voice.

My contradictions never get in my way.

My cut tongue is my serpent sword. I am a warrior woman.

(換到千般恨 “One Thousand Exchanges of

Rooted Hatred," traditional instrumental

Chinese music plays louder, while the

woman gets down from the bench and picks

up the red tulle. Then she sits down on the

red cloaked bench veiling her entire body

loosely with the red tulle, looking down.

Lights and music slowly fade entirely out

together. End.) 


\section{REFERENCES}

Achebe, C. (1959). Things fall apart. New York, NY: Anchor Books.

Aggarwal, R. (2004). Beyond lines of control. Durham, NC: Duke.

Anzaldúa, G. (1987). Borderlands/la frontera: The new mestiza. (2 $2^{\text {nd }}$ ed.). San Francisco, CA: Aunt Lute Books.

Barthes, R. (1977). Image, music, text. New York, NY: Hill and Wang.

Breen, R. (1978). Chamber theatre. Ellison Bay, WI: Wm Caxton Ltd.

Bhabha, H. (1994). The location of culture. New York, NY: Routledge.

Bharucha, R. (2000). The politics of cultural practice: Thinking through theatre through the age of globalization. Hanover, NH: Wesleyan.

Boal, A. (1979). Theatre of the oppressed. New York, NY: Theatre Communications Group.

Bowman, R. \& Bowman, M. (2006). On the bias: From performance of literature to performance composition. In D. S. Madison \& J. Hamera (Eds.), The sage handbook of performance studies. (pp. 205-251). Thousand Oaks, CA: Sage.

Butler, J. (1990). Gender trouble. New York, NY: Routledge.

Carlson, M. (1996). Performance: A critical introduction. New York, NY: Routledge.

Conquergood, D. (1985). Performing as a moral act: Ethical dimensions of the ethnography of performance. Literature in Performance, 5, 1-13.

Conquergood, D. (1993). Storied worlds and the work of teaching. Communication Education, 42, 337-348.

Conquergood, D. (1995). Of caravans and carnivals: Performance studies in motion. The Drama Review, 39, 137-141.

de Certeau, M. (1984). The practice of everyday life. Berkeley, CA: University of California Press.

Diamond, N. (1996). They're coming to America. On The Jazz Singer [CD]. New York: Sony. 
Eisner, R. (2005). Remembering toward loss: Performing And so there are the pieces. In D. Pollock (Ed.), Remembering: Oral history performance. (pp. 101-128). New York, NY: Palgrave Macmillan.

Fanon, F. (1963). The wretched of the earth. New York, NY: Grove Press.

Flores, L. (1996). Creating discursive space through a rhetoric of difference: Chicana feminists craft a homeland. Quarterly Journal of Speech, 82, 142156.

Foucault, M. (1987). What is an author? Albany, NY: State University Press of New York.

Goldman, D. (2006). Ethnography and the politics of adaptation: Leon Forrest's divine days. In D. S. Madison \& J. Hamera (Eds.), The sage handbook of performance studies. (pp. 366-384). Thousand Oaks, CA: Sage.

Haedicke, S. (2002). The politics of participation: Un voyage pas comme les autres sur les chemins de 1'exil. Theatre Topics, 12, 99-118.

Hatcher, J. (1996). The art \& craft of playwriting. Cincinnati, Ohio: Story Press.

Hong Kingston, M. (1975). The woman warrior. New York, NY: Vintage International Edition.

Hutcheon, L. (2006). A theory of adaptation. New York, NY: Routledge.

Johnson, E. P. (2008). Queer theory. In T. C. Davis (Ed.), The cambridge companion to performance studies. (pp. 166-181). Cambridge, UK: Cambridge University Press.

Madison, D. (2005). Critical ethnography: Method, ethics, and performance. Thousand Oaks, CA: Sage.

Moreman, S. T. (2009). Memoir as performance: Strategies of hybrid ethnic identity. Text and Performance Quarterly, 29, 346-366.

Morrison, T. (1970). The bluest eye. New York, NY: Plume.

Pollock, D. (2008). Moving histories: Performance and oral history. In T. C. Davis (Ed.), The cambridge companion to performance studies. (pp. 120-135). Cambridge, UK: Cambridge University Press. 
Said, E. (1979). Orientalism. New York, NY: Vintage Books.

Said, E. (1993). Culture and imperialism. New York, NY: Vintage Books.

Schechner, R. (2002). Performance studies: An introduction. New York, NY: Routledge.

Turner, V. (1982). From ritual to theatre: The human seriousness of play. New York, NY: Performing Arts Journal Publications.

Yeung, P. Y. (1975). I hope your heart remembers me. On Ancient Green [CD]. China: Bestake Records Ltd.

Yordon, J. (1997). Experimental theatre: Creating and staging texts. Prospect Heights, IL: Waveland Press.

Yuan, S. (2001). Cultural politics and Chinese-American female subjectivity: Rethinking Kingston's “woman warrior.” MELUS, 26, 199-223. 